\title{
Adsorptive Removal of Hexavalent Chromium by Diphenylcarbazide-Grafted Macadamia Nutshell Powder
}

\author{
Londolani C. Maremeni, ${ }^{1}$ Sekomeng J. Modise $\mathbb{D D}^{2}{ }^{2}$ \\ Fanyana M. Mtunzi $\left(\mathbb{D},{ }^{1}\right.$ Michael J. Klink $\mathbb{D}^{1}{ }^{1}$ and Vusumzi E. Pakade $\mathbb{D}^{1}$ \\ ${ }^{1}$ Department of Chemistry, Faculty of Applied and Computer Sciences, Vaal University of Technology, Private Bag X021, \\ Vanderbijlpark 1911, South Africa \\ ${ }^{2}$ Institute of Chemical and Biotechnology, Faculty of Applied and Computer Sciences, Vaal University of Technology, \\ Vanderbijlpark 1911, South Africa
}

Correspondence should be addressed to Vusumzi E. Pakade; vusumzip@vut.ac.za

Received 12 February 2018; Accepted 15 March 2018; Published 19 April 2018

Academic Editor: Konstantinos Tsipis

Copyright $\odot 2018$ Londolani C. Maremeni et al. This is an open access article distributed under the Creative Commons Attribution License, which permits unrestricted use, distribution, and reproduction in any medium, provided the original work is properly cited.

\begin{abstract}
Macadamia nutshell powder oxidized by hydrogen peroxide solutions (MHP) was functionalized by immobilizing $1,5^{\prime}$-diphenylcarbazide (DPC) on its surface. The effectiveness of grafting was confirmed by the Fourier transform infrared spectrum due to the presence of $\mathrm{NH}$ and $\mathrm{C}=\mathrm{C}$ stretches at 3361,1591 , and $1486 \mathrm{~cm}^{-1}$, respectively, on the grafted material which were absent in the nongrafted material. Thermogravimetric analysis revealed that the presence of DPC on the surface of Macadamia shells lowered the thermal stability from $300^{\circ} \mathrm{C}$ to about $180^{\circ} \mathrm{C}$ owing to the volatile nature of DPC. Surface roughness as a result of grafting was appreciated on the scanning electron microscopy images. Parameters influencing the adsorptive removal of $\mathrm{Cr}(\mathrm{VI})$ were examined and found to be optimal at $\mathrm{pH} 2$, $120 \mathrm{~min}, 150 \mathrm{mg} / \mathrm{L}$, and $2.5 \mathrm{~g} / \mathrm{L}$. Grafting MHP with DPC leads to an increase in the Langmuir monolayer capacity from 37.74 to $72.12 \mathrm{mg} / \mathrm{g}$. Grafting MHP with DPC produced adsorbent with improved removal efficiency for $\mathrm{Cr}(\mathrm{VI})$.
\end{abstract}

\section{Introduction}

Natural biosorbents like mango kernels, Macadamia nutshells, coconut shells, pine cone, almond shells, sawdust, palm branches, and hazelnut consist in their plant cell walls chiefly the lignin, cellulose, and hemicellulose as the main structural components [1-5]. Consequently, these materials contain a cornucopia of surface functional groups including ketones, aldehydes, esters, ethers, and alcohols. The escalating use of natural biosorbents in adsorption for the remediation of metal pollutants has been largely due to their abundant availability, inexpensiveness, biodegradability, easy desorption, good reusability, and the diverse functional groups they possess which are needed for metal abstraction [6-8]. Further, these materials are regarded as cheap because they require minimum processing. However, when used as adsorbents, some shortfalls like poor surface areas and low adsorption capacities are experienced probably because of the highly cross-linked polymeric nature of the said materials $[1,4,9]$. In addition, upon being used as adsorbents, there is a tendency of small organic molecules trapped within the polymeric cross-linked chains being released into the environments causing high biological oxygen demand and chemical oxygen demand [9]. These drawbacks have restricted the utilization of biosorbents in adsorption in their pristine form.

To address the downfalls, researchers have explored various pretreatment techniques such as (i) biological treatment with fungi or bacteria, (ii) chemical methods using acid, alkaline, oxidation, or solvent extraction, (iii) physical methods through sonication, pyrolysis, or mechanical agitation, and (iv) physicochemical methods, for example, steam explosion $[5,10]$. During pretreatment, surface chemical properties of an adsorbent could be altered through masking 
or elimination of certain groups or exposure to more adsorption sites $[7,11]$. Greater separation of components is achieved much faster and conveniently with chemical pretreatment methods than biological methods [5]. Depending on the intended use of the biomass and the properties desired, various chemical agents, $\mathrm{H}_{2} \mathrm{O}_{2}$ [7], ozone [12], $\mathrm{H}_{3} \mathrm{PO}_{4}$ [13], $\mathrm{HNO}_{3}[14], \mathrm{NaOH}$ [4], and so on, have been reconnoitred for either hydrolysis, oxidation, or delignification [5]. Oxidative chemical treatment could lead to increased oxygenated functionalities like $\mathrm{COOH}, \mathrm{C}-\mathrm{O}-\mathrm{C}, \mathrm{CO}$, and $\mathrm{OH}$ which may then increase metal ion complexation, ion exchange, and chelation $[5,15]$.

To supplement pretreatment methods for improved performance, further modifications (grafting, cross-linking, or polymerization) could be carried out on the surface of adsorbents. Acrylic acid monomer units were grafted on the surface of coir pith, and an adsorption capacity increase from 165 to $196 \mathrm{mg} / \mathrm{g}$ was reported [16]. The improved performance was attributed to the increased density of $-\mathrm{COOH}$ adsorption sites on the material surface. Behbahani et al. [17] grafted 1,5'-diphenylcarbazide on the surface of multiwalled carbon nanotubes for the extraction of $\mathrm{Cd}(\mathrm{II})$ ions from water samples and food products. Extraction efficiency greater than $97 \%$ with a limit of detection (LOD) of $0.05 \mathrm{ng} / \mathrm{mL}$ was achieved. Grafting or polymerization introduces specific functional groups, $\mathrm{NH}, \mathrm{SH}, \mathrm{OH}$, or $\mathrm{COOH}$, on the surface of adsorbents. In a recent study [18], it was shown that modification of natural Populus tremula fibers with amino ligands led to increased adsorption capacity of acid blue 25 from $22.33 \mathrm{mg} / \mathrm{g}$ for unmodified to $48 \mathrm{mg} / \mathrm{g}$ for hydrazine fiber and $67 \mathrm{mg} / \mathrm{g}$ for ethylenediamine fiber. Masau stones were chemically modified with diethylenetriamine through a cross-linking protocol, and $87.32 \mathrm{mg} / \mathrm{g}$ adsorption capacity was reported [19]. The presence of protonated amino groups at acidic conditions was credited to the biosorptioncoupled reduction removal mechanism of $\mathrm{Cr}(\mathrm{VI})$. Similarly, Pakade et al. [20] achieved high adsorption capacity of $145.5 \mathrm{mg} / \mathrm{g}$ following modification of Macadamia nutshellbased carbon with diethylenetriamine and triethylamine ligands. From the mentioned studies, it is obvious that $\mathrm{Cr}(\mathrm{VI})$ has a high affinity for amine functional groups, and it is this narrative that led to the present study where Macadamia nutshells were functionalized, for the first time, with $1,5^{\prime}$ diphenylcarbazide for the eradication of hexavalent chromium from aqueous solution.

Hexavalent chromium [Cr(VI)] and trivalent chromium $[\mathrm{Cr}(\mathrm{III})]$ are the most stable forms of $\mathrm{Cr}$ in the environment. $\mathrm{Cr}(\mathrm{VI})$ is a toxic strong oxidant capable of penetrating the biological cell membranes due to its similarity to sulphates in structure [21]. On the other hand, $\mathrm{Cr}(\mathrm{III})$ is less toxic and is regarded as a micronutrient at minute concentrations but could be toxic if concentrations are high [22]. Exposure to $\mathrm{Cr}(\mathrm{VI})$ compounds may lead to health detrimental effects like lung cancer, kidney damage, epigastric pain, nausea, vomiting, and even death [23, 24]. Careless disposal and improper treatment of effluents from leather tanning, electroplating, textile dyeing, mining, and wood preservation industries lead to contamination of the environment by $\mathrm{Cr}(\mathrm{VI})$ compounds. Owing to their advantages of simplicity, low cost, and fine-tuning of functional groups, adsorption methods have found more applications for the elimination of toxic metals. Therefore, the current study aimed to employ Macadamia nutshells oxidized with $\mathrm{H}_{2} \mathrm{O}_{2}$ in removing $\mathrm{Cr}(\mathrm{VI})$ from aqueous solution and also investigate whether any amelioration in adsorption performance would be achieved following functionalization of $\mathrm{H}_{2} \mathrm{O}_{2}$-treated materials with $1,5^{\prime}$-diphenylcarbazide. Confirmation of the grafting was sought after using the Fourier transform infrared spectroscopy, thermal analysis, and scanning electron microscopy. Adsorption was evaluated by varying $\mathrm{pH}$, time, concentration, and dosage, and various models were used to substantiate the adsorption mechanism involved.

\section{Materials and Methods}

2.1. Chemicals and Instrumentation. Reagent grade potassium dichromate, stannous chloride, ethyl chloride, methanol, toluene, hydrogen peroxide (50\% wt.), sodium hydroxide, hydrochloric acid, and 1,5'-diphenylcarbazide were purchased from LabChem and Merck Chemical Co. (Johannesburg, South Africa) and were used without further purification. $\mathrm{pH}$ adjustments were monitored by HI 2210 from Hanna Instruments (Johannesburg, South Africa), while ultrapure water used for all reactions was obtained from Siemens LaboStar equipment (Warrendale, Pennsylvania, USA). Batch adsorption experiments were conducted in duplicate on an end-over-end Labcon 3100U electrical shaker (Maraisburg, South Africa). Sample preparation and analysis of chromium in solution before and after adsorption was conducted as detailed in our previous studies [4]. Macadamia nutshells were kindly donated by Eastern Produce Estates SA (Pty) Ltd from Tzaneen and Danroc (Pty) Ltd from Barbaton, South Africa.

\subsection{Preparation of Adsorbents}

2.2.1. Chemical Pretreatment. Following removal of debris and dirt, Macadamia nutshells were washed with running tap water and then dried for $24 \mathrm{~h}$ in an oven at $105^{\circ} \mathrm{C}$. The dried nutshells were then ground, milled, and sieved collecting between $90 \mu \mathrm{m}$ and $150 \mu \mathrm{m}$ screens. The collected sample was designated as raw Macadamia nutshells (RMNs). Then, the RMN was oxidized and/or bleached with $20 \%, 35 \%$, and $50 \%(\mathrm{v} / \mathrm{v}) \mathrm{H}_{2} \mathrm{O}_{2}$ solution, resulting in the formation of more oxygen-bearing functional groups on its surface. The resultant materials were labeled $20 \mathrm{MHP}$, $35 \mathrm{MHP}$, and $50 \mathrm{MHP}$ to correspond to the different $\mathrm{H}_{2} \mathrm{O}_{2}$ concentrations used for oxidation of Macadamia nutshell powder. The milling process not only aids with particle size reduction but also could reduce the crystallinity and the degree of polymerization of the polysaccharides in biomass [5] leading to improved adsorption performance.

2.2.2. Functionalization of MHP with Diphenylcarbazide. A method adapted from Behbahani et al. [17] was used with modifications. Briefly, one gram of $20 \mathrm{MHP}$ was suspended in $100 \mathrm{~mL}$ of dry ethyl chloride $\left(\mathrm{CH}_{3} \mathrm{CH}_{2} \mathrm{Cl}_{2}\right)$ under nitrogen $\left(\mathrm{N}_{2}\right)$ atmosphere in a $250 \mathrm{~mL}$ round-neck flask equipped 


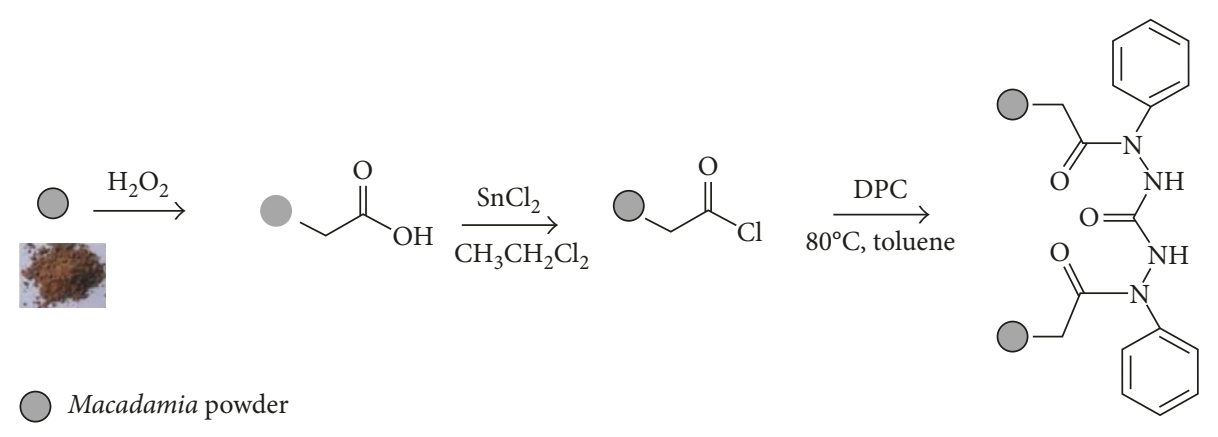

Figure 1: Preparation of diphenylcarbazide-grafted adsorbents.

with a magnetic stirrer and a condenser. About $2 \mathrm{~g}$ of stannous chloride was added to the mixture. Following $24 \mathrm{~h}$ of reflux, the solvent $\left(\mathrm{CH}_{3} \mathrm{CH}_{2} \mathrm{Cl}_{2}\right)$ was removed under reduced pressure and the resultant solid was suspended in toluene. About $5 \mathrm{~g}$ of excess diphenylcarbazide (DPC) was added to the reaction vessel, and the contents were refluxed for further $24 \mathrm{~h}$. On completion, the solid was filtered, washed with toluene and methanol, and then dried at room temperature. The product was labeled $20 \mathrm{MHPD}$ to signify DPC grafting on $20 \mathrm{MHP}$. The same procedure was followed but $20 \mathrm{MHP}$ was replaced with $35 \mathrm{MHP}$ and $50 \mathrm{MHP}$ with the resolution products labeled $35 \mathrm{MHPD}$ and $50 \mathrm{MHPD}$, respectively. Figure 1 shows the preparation procedure.

2.3. Characterization of Adsorbents. Scanning electron microscopic images were obtained from an FEI Quanta 200 SEM (FEI, Hillsboro, OR, USA) and Jeol IT-300 tungsten scanning electron microscopy equipped with secondary backscattering electron detectors and an Oxford energy dispersive X-ray (EDX) analysis external probe. Samples were coated with gold using a Quorum Q150R sputter coater (Quorum Technologies Ltd, East Sussex, UK). The coating thickness was precisely controlled at $5 \mathrm{~nm}$ using the film thickness monitor option of the Quorum Q150R sputter. Functional group analysis on the surface of adsorbents was obtained from a PerkinElmer Spectrum 400 FT-IR/FT-NIR spectrometer (Waltham, MA, USA) recording from 4000 to $500 \mathrm{~cm}^{-1}$. Thermal analysis of adsorbents was elucidated using a PerkinElmer TGA 4000 thermogravimetric analyzer (Waltham, USA). Centrifugation was accomplished employing a CL10 ThermoScientific centrifuge (Johannesburg, South Africa).

2.4. Adsorption Studies. The Macadamia adsorbents (MHP and MHPD) were evaluated for their $\mathrm{Cr}(\mathrm{VI})$ removal efficacy through batch experiments conducted in duplicate. Various parameters that influence adsorption including the effect of $\mathrm{pH}$ ( $\mathrm{pH} 1$ to $\mathrm{pH} 12)$, contact time (20-180 min), initial adsorbate concentration (25 to $150 \mathrm{mg} / \mathrm{L}$ ), and adsorbent dosage $(0.63$ to $10.63 \mathrm{~g} / \mathrm{L})$ were studied. In a typical experiment setup, $0.05 \mathrm{~g}$ of adsorbent was charged to a solution of $\mathrm{Cr}(\mathrm{VI})(20 \mathrm{~mL}$ of $100 \mathrm{mg} / \mathrm{L})$ contained in a $100 \mathrm{~mL}$ glass bottle, and the $\mathrm{pH}$ was adjusted with $\mathrm{HCl}$ or $\mathrm{NaOH}$ diluted solutions. The contents were allowed to react for $120 \mathrm{~min}$ on the electrical shaker followed by solid/liquid separation through centrifugation. The concentration of $\mathrm{Cr}(\mathrm{VI})$ and total $\mathrm{Cr}$ was measured with UV-Vis spectrophotometer $\mathrm{T}^{+} 0^{+}$(PG Instruments) and atomic absorption spectroscopy (AA-7000 from Shimadzu, Kyoto, Japan), respectively, as detailed in our previous studies $[4,25]$. The performance of adsorption was evaluated by calculating the removal percentage $(\% R)$ and maximum adsorption capacity $\left(q_{\mathrm{e}}(\mathrm{mg} / \mathrm{g})\right)$ using (1) and (2), respectively:

$$
\begin{gathered}
\% R=\frac{\left(C_{0}-C_{\mathrm{e}}\right)}{C_{0}} \times 100, \\
q_{\mathrm{e}}=\frac{V\left(C_{0}-C_{\mathrm{e}}\right)}{m},
\end{gathered}
$$

where $C_{\mathrm{e}}$ is the adsorbate equilibrium concentration $(\mathrm{mg} / \mathrm{L})$, $C_{0}$ is the adsorbate initial concentration $(\mathrm{mg} / \mathrm{L}), m$ is the mass of adsorbent $(\mathrm{g})$, and $V$ is the volume of solution used in adsorption (L).

\section{Results and Discussion}

\subsection{Characterization of Materials}

3.1.1. Fourier Transform Infrared Spectroscopy (FTIR) Analysis. Figure 2(a) depicts the Fourier transform infrared spectroscopy (FTIR) spectra of RMN, $20 \mathrm{MHP}, 35 \mathrm{MHP}$, and $50 \mathrm{MHP}$ adsorbents. The hydrogen peroxide-oxidized Macadamia nutshells (MHP) have a broad vibrational stretch at $3330 \mathrm{~cm}^{-1}$ accredited to the presence of bonded $\mathrm{OH}$ groups of the cellulose, $\mathrm{C}=\mathrm{O}$ of carboxyl functional groups at $1728 \mathrm{~cm}^{-1}$, and the $-\mathrm{C}-\mathrm{O}$ stretch of the primary alcohol at $1029 \mathrm{~cm}^{-1}$. The $\mathrm{H}_{2} \mathrm{O}_{2}$ treatment was mild as the structural backbone of the RMN was not greatly altered, but peak shift characteristics of treatment were observed. In accordance with the results reported during chemical treatment of grape peelings with $\mathrm{H}_{2} \mathrm{O}_{2}$ [7] and lightweight expanded clay aggregate adsorbent with aqueous solution of magnesium chloride and hydrogen peroxide [26], no new peaks were observed suggesting a minimal influence of $\mathrm{H}_{2} \mathrm{O}_{2}$ on the chemical structure of biosorbents. The $\mathrm{C}=\mathrm{O}$ band at $1712 \mathrm{~cm}^{-1}$ in the RMN shifted to $1728 \mathrm{~cm}^{-1}$ in MHP adsorbents accompanied by a change in peak shape implying that the $\mathrm{H}_{2} \mathrm{O}_{2}$ yielded $\mathrm{C}=\mathrm{O}$ of a different chemical environment to the $\mathrm{RMN}$. In addition, the $\mathrm{C}-\mathrm{O}$ band of primary alcohols also shifted from 1031 to $1029 \mathrm{~cm}^{-1}$ after peroxide 

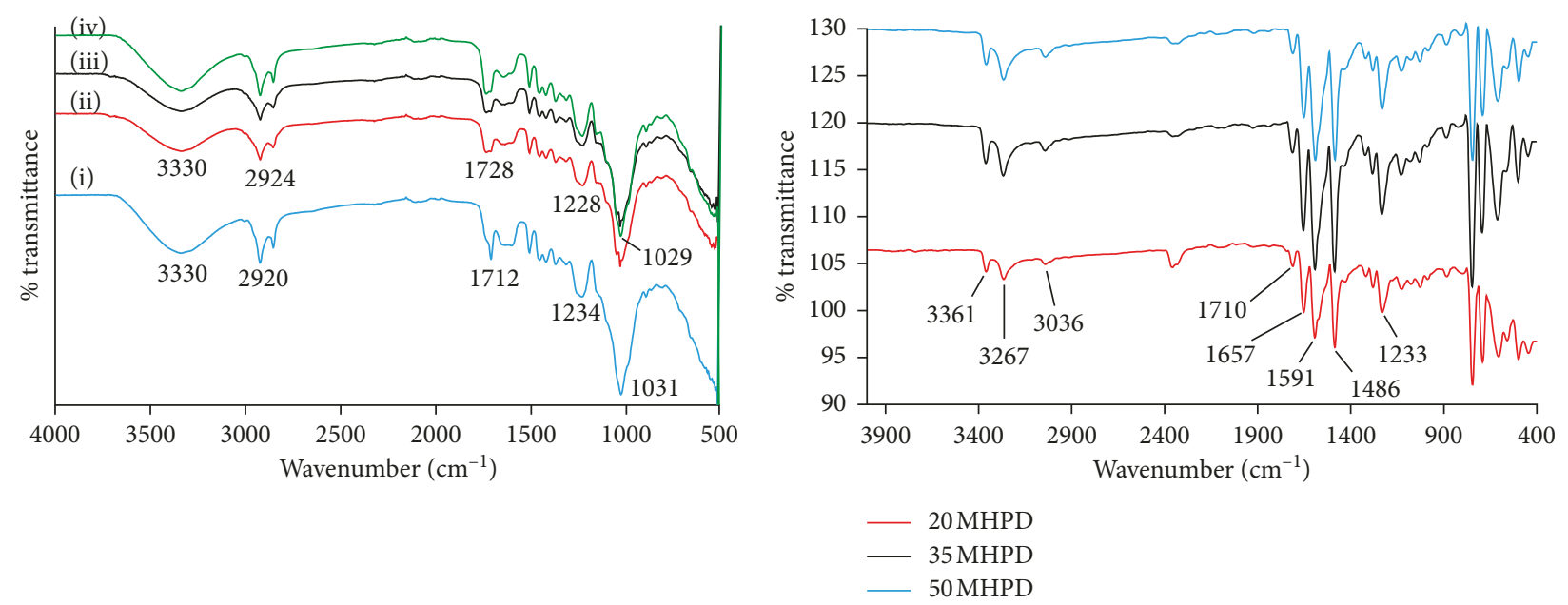

(a)

(b)

Figure 2: (a) FTIR spectra of RMN (i), 20 MHP (ii), 35 MHP (iii), and 50 MHP (iv) adsorbents. (b) FTIR spectra of 20 MHPD, 35 MHPD, and 50 MHPD adsorbents.

treatment. The $-\mathrm{C}-\mathrm{O}-\mathrm{C}$ vibrations shifted from 1234 to $1228 \mathrm{~cm}^{-1}$ after chemical treatment of the RMN with $\mathrm{H}_{2} \mathrm{O}_{2}$ [27]. Immobilization of DPC on MHP resulted in adsorbents with different functional groups as depicted in Figure 2(b). New absorption peaks at $3361 \mathrm{~cm}^{-1}$ attributed to the $-\mathrm{NH}$ stretch of $\mathrm{DPC},-\mathrm{C}=\mathrm{O}$ of the amide at $1657 \mathrm{~cm}^{-1},-\mathrm{CH}$ stretch of the aromatic ring at $3036 \mathrm{~cm}^{-1},-\mathrm{CN}$ stretch at $1233 \mathrm{~cm}^{-1},-\mathrm{CH}$ bending at $743 \mathrm{~cm}^{-1}$, and $-\mathrm{C}=\mathrm{C}$ vibrations of the benzene ring at 1591 and $1486 \mathrm{~cm}^{-1}$ were observed. In addition, absorption peaks due to the parent material were still present: carboxyl $-\mathrm{C}=\mathrm{O}$ at $1710 \mathrm{~cm}^{-1}$ and primary alcohol $-\mathrm{C}-\mathrm{O}$ stretch at $1100 \mathrm{~cm}^{-1}$ [18]. All these observations pointed to the effectiveness of modification and immobilization of the DPC ligand.

3.1.2. Thermogravimetric Analysis (TGA) and Differential Thermal Analysis (DTA). Figure 3 shows the TGA and DTA thermograms for the RMN and MHP. According to Paduraru et al. [28], thermal degradation of biomass follows four distinct stages, namely, the moisture evolution and decomposition of hemicellulose, cellulose, and lignin. These different decomposition stages were also observed with our materials. In all thermograms, the first decomposition observed from $50^{\circ} \mathrm{C}$ to $90^{\circ} \mathrm{C}$ was attributed to the loss of moisture and sorbed water. The second decomposition with the maximum mass loss rate at $318^{\circ} \mathrm{C}, 303^{\circ} \mathrm{C}, 326^{\circ} \mathrm{C}$, and $317^{\circ} \mathrm{C}$ for $\mathrm{RMN}, 20 \mathrm{MHP}, 35 \mathrm{MHP}$, and $50 \mathrm{MHP}$, respectively, was due to degradation of hemicellulose structures. The third decomposition observed at $385^{\circ} \mathrm{C}(\mathrm{RMN})$, $392^{\circ} \mathrm{C}(20 \mathrm{MHP}), 374^{\circ} \mathrm{C}(35 \mathrm{MHP})$, and $382^{\circ} \mathrm{C}(50 \mathrm{MHP})$ was accredited to cellulose structure disintegration. The final degradation which took place beyond hemicellulose degradation was attributed to the slow decomposition of lignin. In addition, the RMN, $20 \mathrm{MHP}$, and $35 \mathrm{MHP}$ displayed loss of volatile components, probably $\mathrm{CH}_{4}, \mathrm{H}_{2}, \mathrm{CO}_{2}$, or $\mathrm{CO}$, at about $250^{\circ} \mathrm{C}$, and this was absent in $50 \mathrm{MHP}$ adsorbent probably because the $50 \%(\mathrm{v} / \mathrm{v}) \mathrm{H}_{2} \mathrm{O}_{2}$ treatment was too harsh and eliminated all the volatile components Yang et al. [29] also observed evolution of volatile compounds $\left(\mathrm{CH}_{4}\right.$, $\mathrm{H}_{2}, \mathrm{CO}_{2}$, and $\mathrm{CO}$ ) at temperatures below $300^{\circ} \mathrm{C}$ during pyrolysis of hemicellulose. The exact degradation temperatures of cellulose and hemicellulose were different in all materials indicating that the treatment influenced the structure and surface properties of these materials.

The DPC-grafted materials exhibited distinct thermograms compared to the $\mathrm{H}_{2} \mathrm{O}_{2}$-treated materials. The thermograms are shown in Figure 4. In all thermograms, loss of moisture and adsorbed water was observed at about $80^{\circ} \mathrm{C}$. The more pronounced degradation at about $205^{\circ} \mathrm{C}$ was attributed to the decomposition of DPC from MHPD. Another notable peak was at $270^{\circ} \mathrm{C}$ attributable to the decomposition of cellulosic structures. Slow degradation of lignin can be appreciated from $335^{\circ} \mathrm{C}$ onwards. Clearly, the $50 \mathrm{MHPD}$ exhibited slightly different decomposition peak shapes. Dhakal et al. [30] alluded that the difference in peak shapes and decomposition temperatures showed that the structural backbone of the adsorbents was affected by the chemical treatment to which they were exposed to.

3.1.3. Scanning Electron Microscopy (SEM). The morphological properties of the adsorbent surface were elucidated using scanning electron microscopy (SEM). The SEM images for MHP and MHPD adsorbents are shown in Figure 5. RMN SEM was typical of plant material SEM with rough surface texture and scaling but with no observable porosity [4]. Upon treatment with $\mathrm{H}_{2} \mathrm{O}_{2}$, some surface porosity was observed as round spots in MHP samples. Grafting MHP with DPC yielded materials with much rougher texture, but pores disappeared. The differences in surface topographies between MHP and MHPD adsorbents proved that functionalization did occur. The disappearance of open pores due to grafting was observed elsewhere [31], while Albadarin et al. [19] also noted differences in surface topographies of 


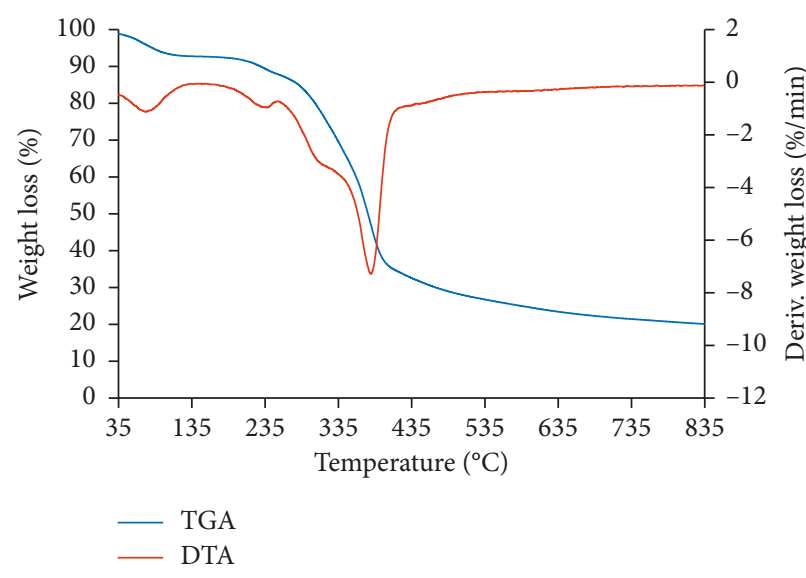

(a)

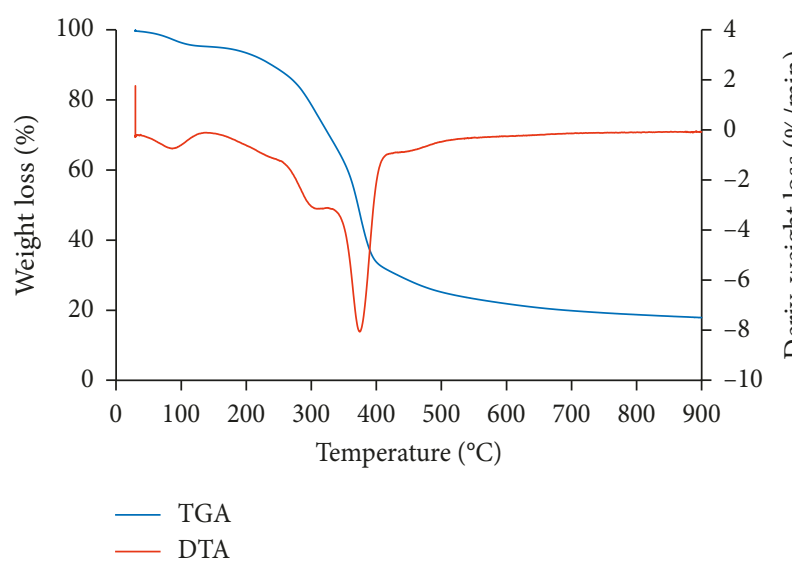

(c)

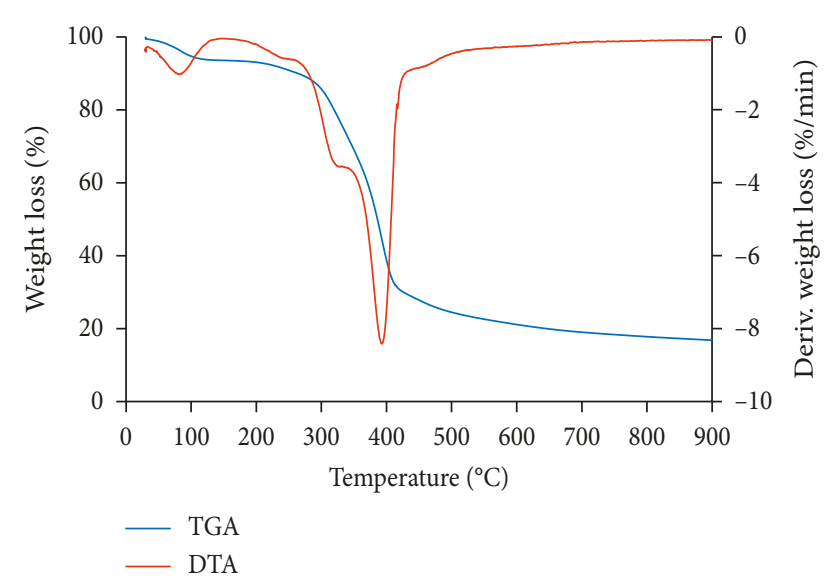

(b)

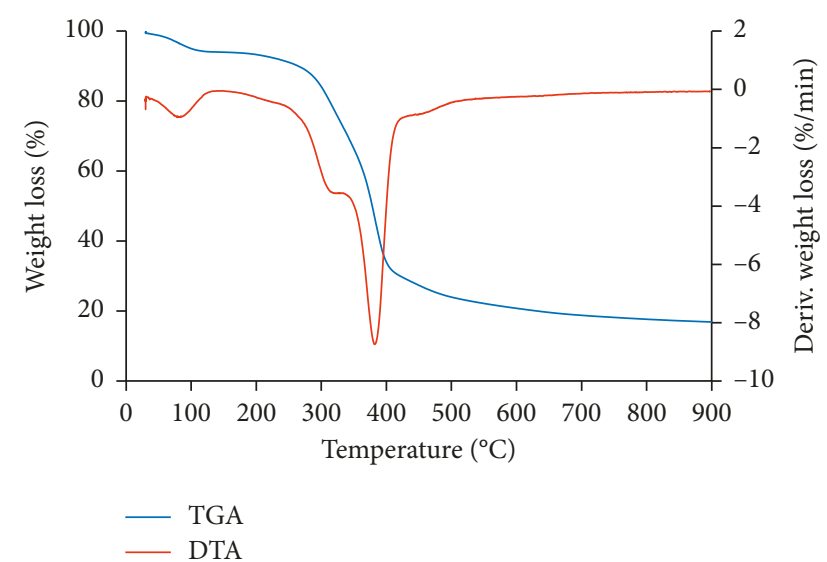

(d)

Figure 3: (a)TGA and DTA thermograms for RMN (a), 20 MHP (b), 35 MHP (c), and 50 MHP (d) adsorbents.

amine-modified masau stones incurred by chemical treatment.

3.1.4. Brunauer-Emmett-Teller (BET) Analysis. The Brunauer-Emmett-Teller (BET) surface analysis was carried out to assess the pore volume, surface area, and pore size of the adsorbents. Table 1 lists the BET, surface area, pore volume and pore diameter results for MHP and MHPD adsorbents. Typical of biomass, the surface area values were relatively small ranging from 0.0063 to $0.5093 \mathrm{~m}^{2} / \mathrm{g}$. It seems that grafting of DPC on MHP decreased the surface areas as in the case of $35 \mathrm{MHP}\left(1.0019 \mathrm{~m}^{2} / \mathrm{g}\right)$ and $35 \mathrm{MHPD}$ $\left(0.2034 \mathrm{~m}^{2} / \mathrm{g}\right)$ as a result of surface coverage. On the contrary, the surface area for $20 \mathrm{MHP}$ increased to $0.5093 \mathrm{~m}^{2} / \mathrm{g}$ after DPC grafting. Surface areas in the range of 2.8 to $6.3 \mathrm{~m}^{2} / \mathrm{g}$ for palm branches [32] and from 3.1477 to $3.6672 \mathrm{~m}^{2} / \mathrm{g}$ for peat and coconut fibers [33] have been reported.

\subsection{Adsorption Experiments}

3.2.1. Effect of $p H$. The effect of $\mathrm{pH}$ on the removal of hexavalent chromium by $20 \mathrm{MHP}, 35 \mathrm{MHP}, 50 \mathrm{MHP}$, $20 \mathrm{MHPD}, 35 \mathrm{MHPD}$, and $50 \mathrm{MHPD}$ was carried out in batch adsorption experiments by varying the $\mathrm{pH}$ from 1 to 12 while the initial concentration of $\mathrm{Cr}(\mathrm{VI})$ was $150 \mathrm{mg} / \mathrm{L}$ and the adsorbent dose was $2.5 \mathrm{~g} / \mathrm{L}$. The results are displayed as $\% R$ versus initial $\mathrm{pH}$ in Figure 6. Both the MHP and the MHPD adsorbents exhibited a similar trend where $\% R$ decreased as the initial $\mathrm{pH}$ of the solution was increased from 1 to 12 . Highest removal of $\mathrm{Cr}(\mathrm{VI})$ took place at $\mathrm{pH}$, but there was a clear separation in terms of performance between the MHP and MHPD adsorbents, with the latter exhibiting superior removal starting at $90 \%$ and decreasing to $79 \%$, while the former ranged from $50 \%$ to $4 \%$ removal. That is, all these adsorbents showed a strong dependence in solution $\mathrm{pH}$ where maximum adsorption occurred at acidic conditions $[4,34]$. The high removal at low $\mathrm{pH}$ is the result of electrostatic attraction between positively charged adsorbent sites (protonation) $\left(\mathrm{COOH}_{2}{ }^{+}\right.$and $\mathrm{OH}_{2}{ }^{+}$for $\mathrm{MHP}$ and $\mathrm{NH}^{+}$ for MHPD) and the hydrogen chromate ions [35]. Hydrogen chromate $\left(\mathrm{HCrO}_{4}{ }^{-}\right)$is usually the most dominant $\mathrm{Cr}(\mathrm{VI})$ species at acidic conditions and under oxidizing conditions. On the other hand, dichromate $\left(\mathrm{Cr}_{2} \mathrm{O}_{7}{ }^{2-}\right)$ is stable at weakly acidic and low oxidizing conditions, but as the $\mathrm{pH}$ is increased towards the basic region, the equilibrium tends to shift to chromate $\left(\mathrm{CrO}_{4}{ }^{2-}\right)[25,32]$. The decline in $\% R$ as the $\mathrm{pH}$ was increased could be due to the depletion of protons resulting in less protonated sites and more $\mathrm{OH}^{-}$groups that can lead to competition with chromate ions for adsorption 


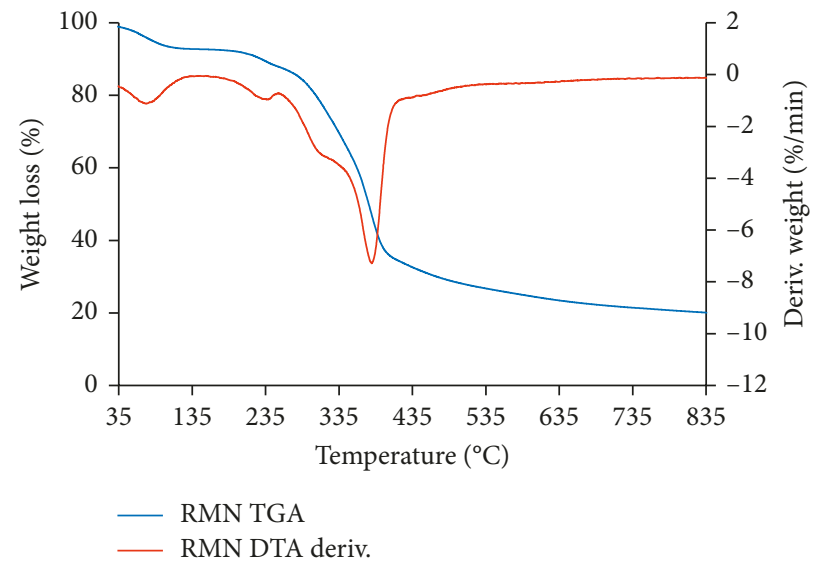

(a)

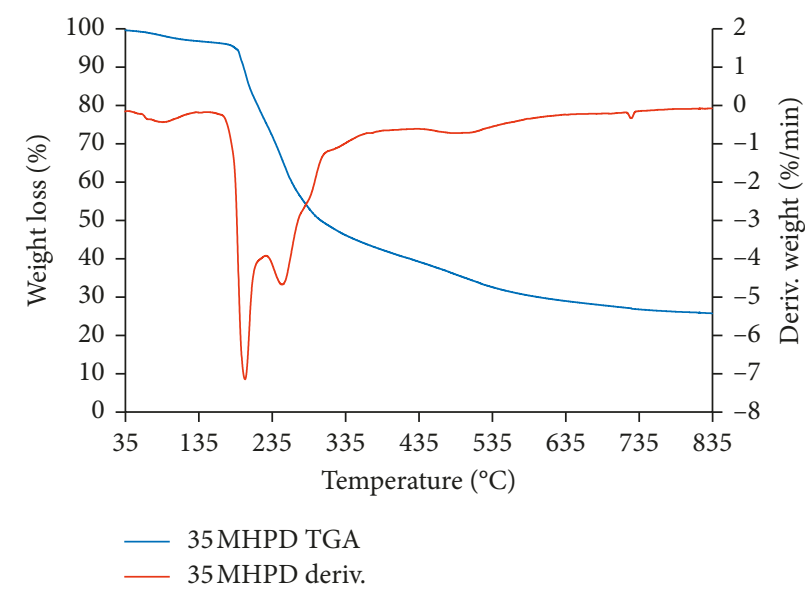

(c)

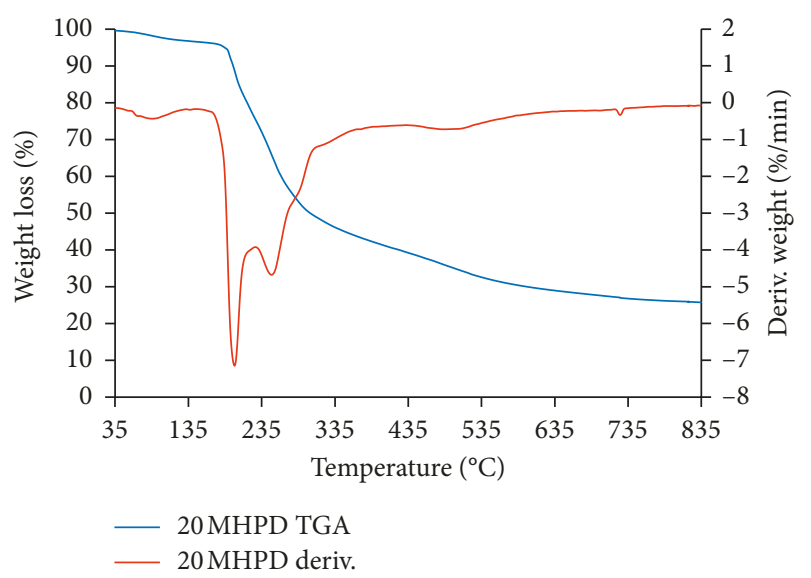

(b)

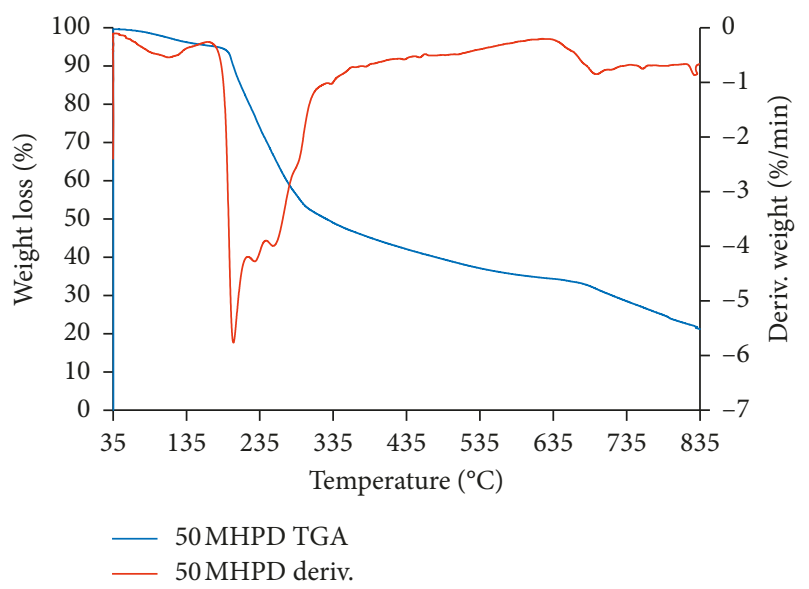

(d)

Figure 4: TGA and DTA thermograms for RMN (a), 20 MHPD (b), 35 MHPD (c), and 50 MHPD (d) adsorbents.

sites. Similar $\mathrm{pH}$ efficiency trends have been reported by several researchers [20,31, 35-37]. Besides the predicted electrostatic attraction of $\mathrm{Cr}(\mathrm{VI})$ to the cationic group mechanism, the reduction of $\mathrm{Cr}(\mathrm{VI})$ to $\mathrm{Cr}$ (III) cannot be ruled out because it has been demonstrated in the past that Macadamia nutshell-based adsorbents favored adsorptioncoupled reduction uptake of $\mathrm{Cr}(\mathrm{VI})[4,38]$.

3.2.2. Effect of Contact Time and Kinetics. To investigate the feasibility and efficiency of $\mathrm{Cr}(\mathrm{VI})$ adsorption onto MHP and MHPD adsorbents, contact time was varied from 20 to $180 \mathrm{~min}$, while all other parameters were kept constant. The \% removal of $\mathrm{Cr}(\mathrm{VI})$ by MHP and MHPD as a function of time is shown in Figure 7. Two distinct sets of results were observed where the MHP adsorbents performed poorly compared to MHPD. The $\% R$ for MHP adsorbents increased from 12 to $70 \%$ as time was varied from 20 to $180 \mathrm{~min}$ and seemed to not have reached equilibrium even after $180 \mathrm{~min}$ of contact time. This could mean that the process of adsorption by MHP adsorbents was quite slow as there were adsorption sites not accessible after $180 \mathrm{~min}$ of reaction time. The order of adsorption efficiency was $50 \mathrm{MHP}>35 \mathrm{MHP}>20 \mathrm{MHP}$. Grafting MHP with DPC yielded adsorbents with better performance in terms of $\% R$ and reaction kinetics. The $\% R$ of $\mathrm{MHPD}$ was much higher than that of MHP ranging from 65 to $98 \%$, while the saturation was achieved only after $40 \mathrm{~min}$. In some of these curves, the three stages of adsorption processes were notable, that is, the boundary layer saturation (20 to $30 \mathrm{~min}$ ), diffusion into internal pores (30 to $40 \mathrm{~min}$ ), and equilibration (beyond $40 \mathrm{~min}$ ). The high affinity of the adsorbate to adsorption sites (physical adsorption or ion exchange) was associated with the higher sorption rate at initial times [34]. MHPD adsorbents possessed more functional groups with better accessibility due to the high affinity of $\mathrm{Cr}$ (VI) for protonated amino groups. The order of efficiency was $20 \mathrm{MHPD}>50 \mathrm{MHPD}>35 \mathrm{MHPD}$.

3.2.3. Kinetic Parameters. Pseudo-first-order [39] and pseudo-second-order [40] kinetic models were employed to study the kinetic parameters governing the adsorption of $\mathrm{Cr}(\mathrm{VI})$ to MHP and MHPD adsorbents. The time dependency data were fitted into nonlinear pseudo-first-order (PFO) and pseudo-second-order (PSO) equations (3) and (4). The results as illustrated in Table 2 revealed that all the adsorbents, except $20 \mathrm{MHP}$ and $35 \mathrm{MHPD}$, followed the PSO rate model as judged by the higher coefficient of correlation $\left(R^{2}\right)$, lower $X^{2}$, 


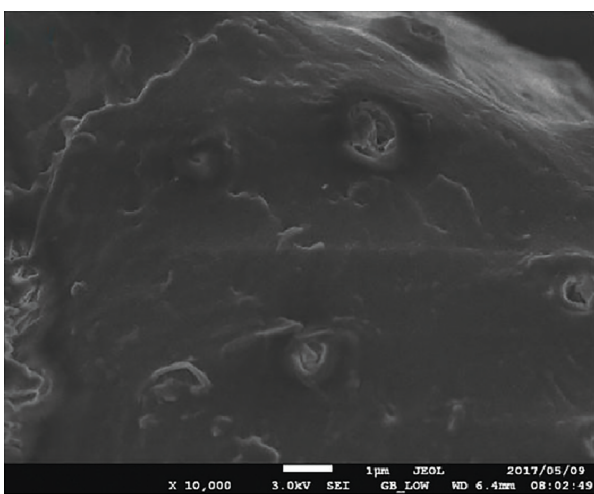

(a)

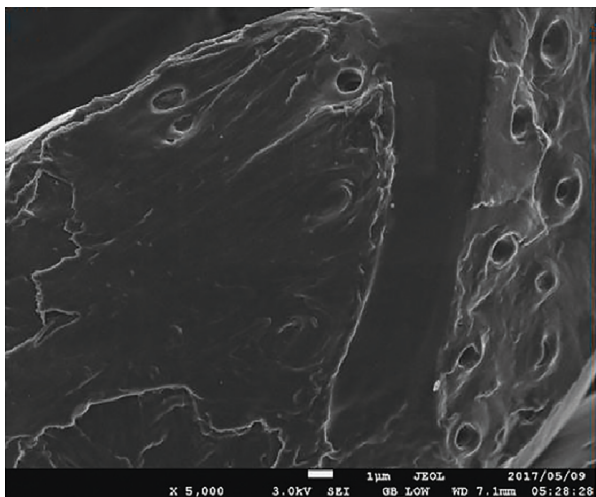

(c)

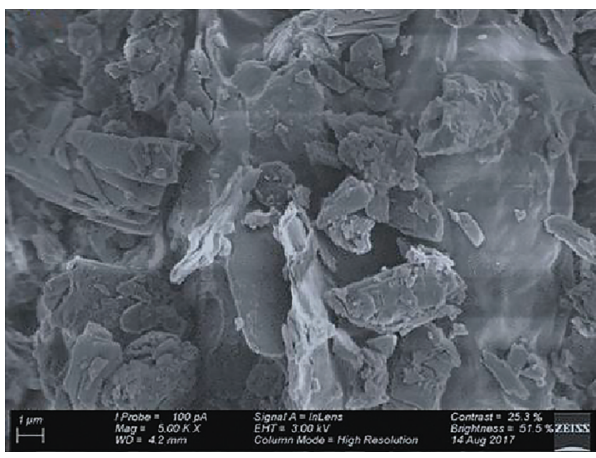

(e)

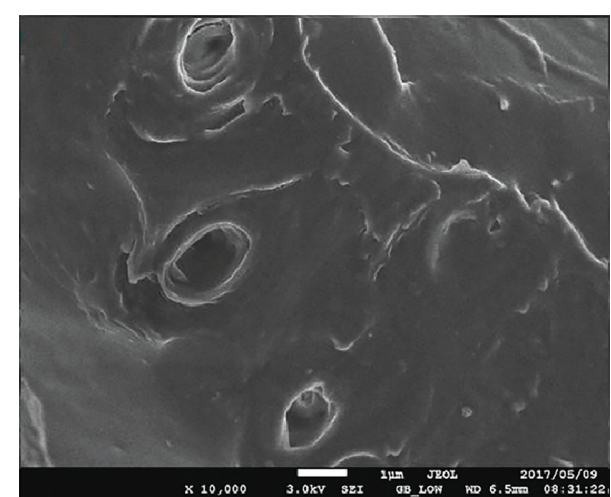

(b)

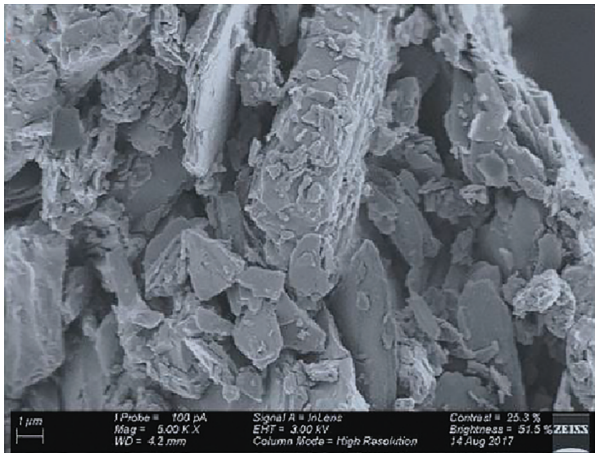

(d)

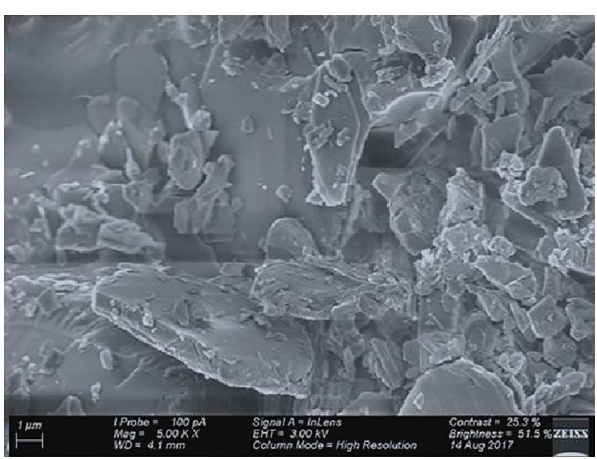

(f)

Figure 5: Scanning electron microscopic images for 20 MHP (a), 35 MHP (b), 50 MHP (c), 20 MHPD (d), 35 MHPD (e), and 50 MHPD (f).

and closeness of $q_{\mathrm{t}}$ to $q_{\mathrm{e}}$ values in PSO in comparison to the PFO model. It could then be inferred that PSO represented the adsorption of $\mathrm{Cr}(\mathrm{VI})$ by all MHP and MHPD adsorbents barring the $20 \mathrm{MHP}$ and $35 \mathrm{MHPD}$ which obeyed PFO. The adsorbents obeying PSO were predicted to favor chemisorption [31, 33], while those described by PFO favored physisorption [18]. It has been argued by Albadarin et al. [19] that the PFO and PSO kinetic models are empirical equations and therefore not fully account for the chemical and physical interactions of adsorbates. The complex nature of $\mathrm{Cr}(\mathrm{VI})$ interaction with adsorbents (i.e., adsorption/reduction) makes it difficult to explain the mechanism with only one model as is the case with $20 \mathrm{MHP}$. The $k$ values were relatively small, implying that the sorption process required more time to approach saturation [19].

$$
\begin{aligned}
& q_{\mathrm{t}}=q_{\mathrm{e}}\left(1-\exp ^{-k} 1^{t}\right), \\
& q_{\mathrm{t}}=\frac{t k_{2} \cdot q_{\mathrm{e}}^{2}}{\left(1+k_{2} t q_{\mathrm{e}}\right)},
\end{aligned}
$$

where $k_{1}(1 / \mathrm{min})$ is the PFO rate constant, $q_{\mathrm{t}}(\mathrm{mg} / \mathrm{g})$ is the amount of $\mathrm{Cr}(\mathrm{VI})$ (mg) adsorbed by the adsorbent (g) at time $t$, and $k_{2}(\mathrm{~g} / \mathrm{mg} \mathrm{min})$ is the PSO rate constant.

3.2.4. Intraparticle and Liquid Film Diffusion. Intraparticle and/or film diffusion (external mass transfer) represent possible mechanisms by which adsorption of adsorbates onto porous materials could take place [41]. The intraparticle diffusion model proposed by Weber et al. [42] represented 
TABLE 1: BET surface characterization.

\begin{tabular}{lccc}
\hline \multirow{2}{*}{ Adsorbents } & \multicolumn{2}{c}{ Surface characterization } \\
& Pore volume $\left(\mathrm{cm}^{3} / \mathrm{g}\right)$ & BET surface area $\left(\mathrm{m}^{2} / \mathrm{g}\right)$ & Pore size $(\mathrm{nm})$ \\
\hline $20 \mathrm{MHP}$ & - & 0.0063 & - \\
$35 \mathrm{MHP}$ & 0.002717 & 1.0019 & 10.85013 \\
$50 \mathrm{MHP}$ & - & 0.5093 & - \\
$20 \mathrm{MHPD}$ & - & 0.1047 & - \\
$35 \mathrm{MHPD}$ & - & 0.2034 & - \\
50 MHPD & - & 0.0647 & - \\
\hline
\end{tabular}

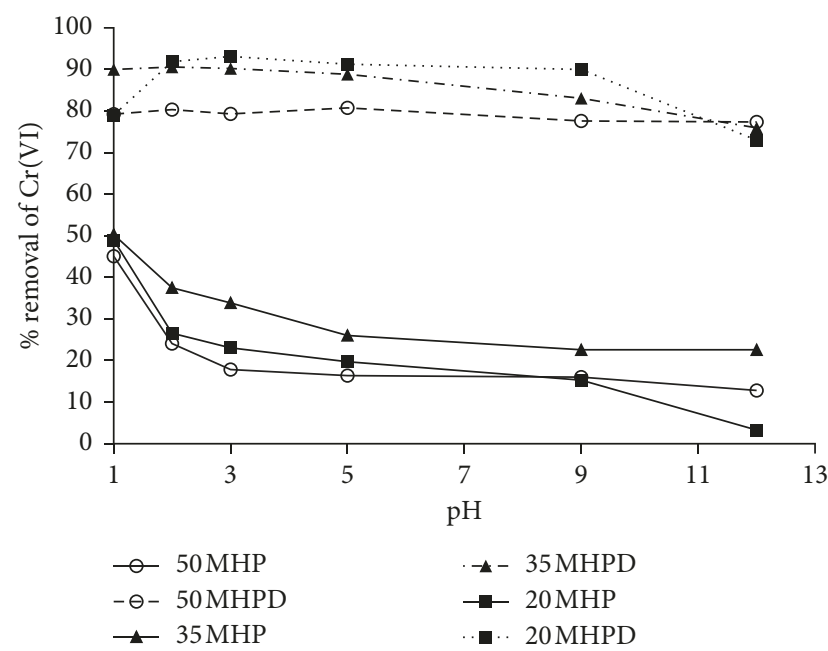

FIgURE 6: Effect of initial solution $\mathrm{pH}$ on the removal of $\mathrm{Cr}(\mathrm{VI})$ by MHP and MHPD adsorbents (conditions: initial $\mathrm{Cr}(\mathrm{VI})$ concentration $150 \mathrm{mg} / \mathrm{L}$; dosage $2.5 \mathrm{~g} / \mathrm{L}$; and time $120 \mathrm{~min}$ ).

here by (5) was used to determine the rate-controlling steps and mechanism of adsorption of $\mathrm{Cr}(\mathrm{VI})$. In addition, liquid film diffusion was evaluated by fitting the data into (6).

$$
\begin{aligned}
q_{\mathrm{t}} & =k_{\mathrm{d}} t^{0.5}+C, \\
\operatorname{Ln}\left(1-\frac{q_{\mathrm{t}}}{q_{\mathrm{e}}}\right) & =-k_{\mathrm{fd}} t,
\end{aligned}
$$

where $k_{\mathrm{d}}\left(\mathrm{mg} /\left(\mathrm{g} \cdot \mathrm{min}^{0.5}\right)\right)$ is the rate constant for intraparticle diffusion, $k_{\mathrm{fd}}$ is the film diffusion rate constant, and the boundary layer thickness is represented by the intercept C (mg/g). According to literature [43-45], intraparticle diffusion is deemed the only rate-controlling step when the plots of $q_{\mathrm{t}}$ versus $t^{0.5}$ yield a straight line passing through the origin. It can be seen in Figures $8(a)$ and $8(\mathrm{c})$ that the adsorbents exhibited different mechanisms, that is, linear line over the entire time interval (20 MHP, $35 \mathrm{MHP}, 20 \mathrm{MHPD}$, and $50 \mathrm{MHPD}$ ) and multilinearity (50 MHP and $35 \mathrm{MHPD})$. Even those that were straight lines, none passed through the origin but implied the dominance of the intraparticle diffusion mechanism and insignificant mass transfer resistance. The curves with multilinearity showed the existence of film diffusion (the first steep curve) and intraparticle diffusion (the second flat curve). Assessment of the liquid thin-film diffusion model (Figures 8(b) and 8(d)) shows great linearity

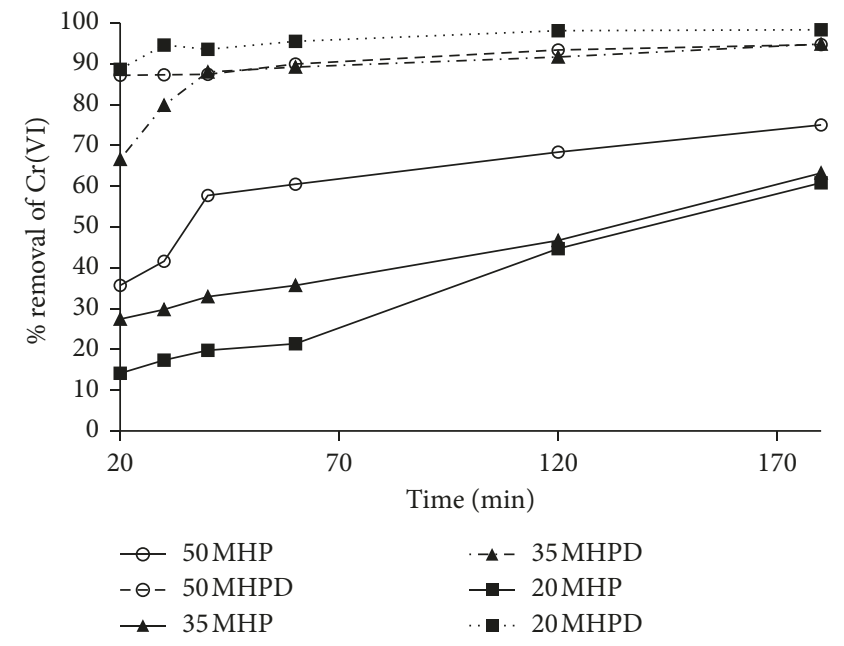

FIGURE 7: Effect of contact time for the removal of $\mathrm{Cr}(\mathrm{VI})$ by MHP and MHPD adsorbents (conditions: initial $\mathrm{Cr}(\mathrm{VI})$ concentration $150 \mathrm{mg} / \mathrm{L}$; dosage $2.5 \mathrm{~g} / \mathrm{L}$; and $\mathrm{pH} 1$ ).

with $R^{2}>0.98$, but lines did not pass through the origin point suggesting that film diffusion was also not the only rate-limiting step.

3.2.5. Effect of Initial Concentration and Adsorption Isotherms. Figure 9 shows the adsorption capacity $\left(q_{\mathrm{e}}\right)$ as a function of initial adsorbate concentration. It can be appreciated that the adsorption capacities increased as the initial concentration of $\mathrm{Cr}(\mathrm{VI})$ was increased from 20 to $180 \mathrm{mg} / \mathrm{L}$. The magnitudes of $q_{\mathrm{e}}$ varied as follows: 4.9 to $15 \mathrm{mg} / \mathrm{g}$ for $20 \mathrm{MHP}, 5.1$ to $20 \mathrm{mg} / \mathrm{g}$ for $35 \mathrm{MHP}, 5.1$ to $40 \mathrm{mg} / \mathrm{g}$ for $50 \mathrm{MHP}, 6$ to $70 \mathrm{mg} / \mathrm{g}$ for $20 \mathrm{MHPD}, 7$ to $50 \mathrm{mg} / \mathrm{g}$ for $35 \mathrm{MHPD}$, and 7 to $74 \mathrm{mg} / \mathrm{g}$ for $50 \mathrm{MHPD}$. These results clearly showed that the adsorption of $\mathrm{Cr}(\mathrm{VI})$ was concentration dependent, that no saturation was realized except $20 \mathrm{MHP}$ and $35 \mathrm{MHP}$, and that MHPD adsorbents were superior to MHP adsorbents. The increase in sorption capacity as concentration was increased could be explained on the basis that, at low adsorbate concentrations, the number of available adsorption sites compared to $\mathrm{Cr}(\mathrm{VI})$ ions was higher leading to higher $\mathrm{Cr}(\mathrm{VI})$ removal, but as the initial concentration of $\mathrm{Cr}(\mathrm{VI})$ was increased, this ratio (adsorption site/Cr(VI) ion) decreased resulting in saturation, lesser $\% R$, and higher adsorption capacities [25, 36, 46]. 
TABLE 2: PFO and PSO kinetic parameters for adsorption of $\mathrm{Cr}(\mathrm{VI})$ by MHP and MHPD.

\begin{tabular}{|c|c|c|c|c|c|c|}
\hline Parameters & $20 \mathrm{MHP}$ & $35 \mathrm{MHP}$ & $50 \mathrm{MHP}$ & 20 MHPD & 35 MHPD & $50 \mathrm{MHPD}$ \\
\hline$q_{\mathrm{t}}(\mathrm{mg} / \mathrm{g})$ & 18.11 & 18.96 & 22.5 & 58.77 & 56.89 & 56.81 \\
\hline$q_{\mathrm{e}}(\mathrm{mg} / \mathrm{g})$ & 21.26 & 17.05 & 21.77 & 57.96 & 55.80 & 53.58 \\
\hline$k_{1}(1 / \mathrm{min})$ & 0.0107 & 0.0224 & 0.0325 & 0.1286 & 0.0644 & 0.151 \\
\hline$R^{2}$ & 0.939 & 0.615 & 0.940 & 0.799 & 0.967 & 0.637 \\
\hline$X^{2}$ & 41.71 & 14.04 & 11.24 & 0.40 & 5.93 & 0.780 \\
\hline$q_{\mathrm{e}}(\mathrm{mg} / \mathrm{g})$ & 31.09 & 20.82 & 25.73 & 59.52 & 60.25 & 56.78 \\
\hline$k_{2}(\mathrm{~g} / \mathrm{mg} \mathrm{min})$ & 0.0025 & 0.00117 & 0.00147 & 0.0085 & 0.00198 & 0.00863 \\
\hline$R^{2}$ & 0.942 & 0.725 & 0.936 & 0.896 & 0.881 & 0.887 \\
\hline$X^{2}$ & 89.12 & 26.83 & 22.1 & 0.95 & 11.72 & 2.19 \\
\hline
\end{tabular}

To account for the interaction between $\mathrm{Cr}(\mathrm{VI})$ and MHPD adsorbents, nonlinear Langmuir and Freundlich adsorption isotherms were used to model the adsorption equilibrium data from the effect of concentration. The Langmuir pertains to monolayer adsorption of adsorbates onto homogeneous adsorption sites, while the Freundlich advocates the multilayer adsorption mechanism on heterogeneous sites. Table 3 illustrates the adsorption constants obtained from the isotherms. Comparing the MHP adsorbents using the coefficient of determination $\left(R^{2}\right)$ and the variance, it can be seen that the Freundlich model exhibited higher $R^{2}$ values and lower variance. In addition, the $q_{\mathrm{e}}$ and Langmuir $q_{\mathrm{m}}$ values were not closer together. Therefore, it was concluded that the data for MHP were best described by the Freundlich model, implicating that the mechanism of removal was a multilayer process on heterogeneous adsorption sites. The Freundlich $1 / n_{\mathrm{F}}$ values were less than unity indicating a feasible and favorable adsorption of $\mathrm{Cr}(\mathrm{VI})$ on the MHP surface.

\subsubsection{Effect of Dosage and Adsorption Capacity} Comparison. Figures $10(\mathrm{a})$ and $10(\mathrm{~b})$ portray the $\% R$ of $\mathrm{Cr}(\mathrm{VI})$ as a function of adsorbent dosage for MHP and MHPD adsorbents. In both cases, the $\% R$ of $\mathrm{Cr}(\mathrm{VI})$ increased with increasing dose levels from 0.63 to $10.63 \mathrm{~g} / \mathrm{L}$. The $\% R$ increased sharply from 50 to $88 \%$ as the dose was increased from 0.63 to $4.63 \mathrm{~g} / \mathrm{L}$ and slowed down afterward almost reaching equilibrium for MHP adsorbents at $92 \%$ removal. For MHPD adsorbents, the $\% R$ increased steeply from 67 to $93 \%$ when the dosage was increased from 0.63 to $2.63 \mathrm{~g} / \mathrm{L}$ and only increased to $95 \%$ afterward as equilibrium was attained. It is clear that MHPD adsorbents were superior to MHP adsorbents as only half the dosage $(2.63 \mathrm{~g} / \mathrm{L})$ was needed to achieve the same maximum $\% R$ by MHP at $4.63 \mathrm{~g} / \mathrm{L}$. The increased removal at higher doses could be due to the presence of more adsorption sites leading to high ion exchange capacity and surface area $[5,34,36]$. In both cases, the adsorption capacity decreased as the dose was increased probably because there was overlapping resulting from overcrowding of adsorption sites [47].

The performance of the prepared adsorbents was demonstrated by comparing their adsorption capacities to those of other biosorbents found in the literature. The results illustrated in Table 4 revealed that adsorption capacities of adsorbents may vary widely making it difficult to compare because of different experimental conditions (dosage, $\mathrm{pH}$, adsorbate concentration, stirring rate, shaking versus stirring, and column versus batch) used. Nonetheless, the present result was comparable to other adsorbents but lower than others.

3.3. Selectivity of $\mathrm{Cr}(\mathrm{VI})$ Ion. Investigation of the effect of competing ions is paramount for any developed adsorbent because pollutants often exist together with a host of other chemicals including organic, inorganic, and biological materials. It has been shown that the presence of sulphates and nitrates impacted the removal of $\mathrm{Cr}(\mathrm{VI})$ negatively [15, $48,49]$. In this study, a concoction of a solution containing $150 \mathrm{mg} / \mathrm{L}$ of each of $\mathrm{Cr}(\mathrm{VI}), \mathrm{SO}_{4}{ }^{2-}, \mathrm{Cl}^{-}$, and $\mathrm{NO}_{3}{ }^{-}$was prepared from their respective salts and used to investigate the effect of co-ions on adsorption of $\mathrm{Cr}(\mathrm{VI})$. Another solution containing only $\mathrm{Cr}(\mathrm{VI})$ was used as a control. The results depicting the $\% R$ of $\mathrm{Cr}(\mathrm{VI})$ in the presence and absence of co-ions are presented in Figure 11. The percent removal of $\mathrm{Cr}(\mathrm{VI})$ decreased from 80 to $79 \%$ for $20 \mathrm{MHP}, 87$ to $80 \%$ for $50 \mathrm{MHP}, 95$ to $93 \%$ for $20 \mathrm{MHPD}$, and 85 to $82 \%$ for 50 MHPD, while the $\% R$ was exactly the same for 35 MHPD but the removal was higher in the presence of co-ions when $35 \mathrm{MHP}$ was used. The $50 \mathrm{MHPD}$ adsorbents showed superior selectivity than 20 MHPD and 35 MHPD. The latter was negatively affected by the presence of competing ions, but still, the $\% R$ was still greater than $80 \%$. The prepared adsorbents demonstrated good recognition of $\mathrm{Cr}(\mathrm{VI})$ in the presence of competing ions and can thus be recommended as alternative low-cost adsorbents for the mitigation of $\mathrm{Cr}(\mathrm{VI})$.

3.4. Application to Real-World Sample. A wastewater sample with the chemical qualities $\mathrm{Cr}^{3+}(4 \mathrm{mg} / \mathrm{L}), \mathrm{Zn}^{2+}(1 \mathrm{mg} / \mathrm{L})$, $\mathrm{Fe}^{2+}(6 \mathrm{mg} / \mathrm{L}), \mathrm{Ni}^{2+}(2 \mathrm{mg} / \mathrm{L})$, and $\mathrm{Cu}^{2+}(31 \mathrm{mg} / \mathrm{L})$ was used to investigate the performance of the developed adsorbents in a real-world sample. All were prepared from their chloride salts. The sample was spiked with $30 \mathrm{mg} / \mathrm{L} \mathrm{Cr}(\mathrm{VI})$. Figure 12 shows the results of $\% R$ of $\mathrm{Cr}(\mathrm{VI})$ from the spiked solution by MHPD adsorbents. The efficiency in the removal of $\mathrm{Cr}(\mathrm{VI})$ by $\mathrm{MHP}$ adsorbents decreased in the order $20 \mathrm{MHP}>35 \mathrm{MHP}>50 \mathrm{MHP}$ from $82 \%$, 75\%, and 53\% removal, respectively. In contrast, the removal increased in the order $80 \%, 85 \%$, and $88 \%$ for 20 MHPD, $35 \mathrm{MHPD}$, and $50 \mathrm{MHPD}$, respectively. The decrease in $\% R$ as the percent of 


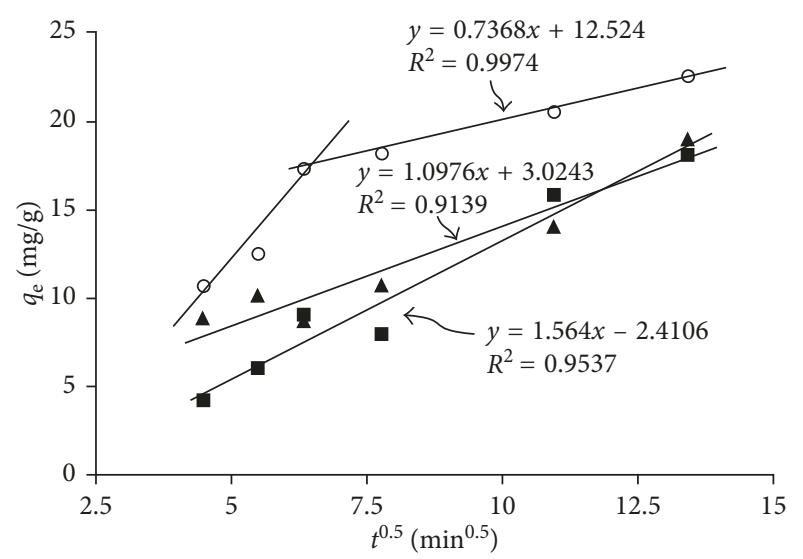

- $20 \mathrm{MHP}$

- $35 \mathrm{MHP}$

○ $50 \mathrm{MHP}$

(a)

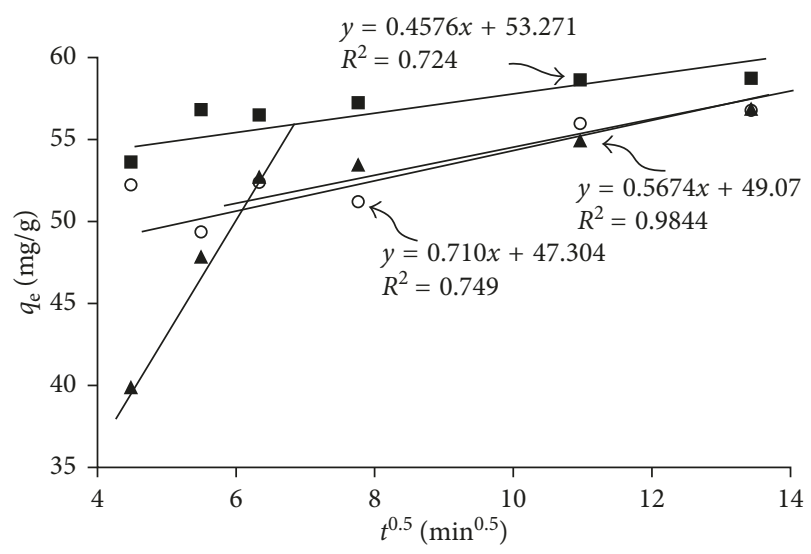

- 20MHPD

35MHPD

○ $50 \mathrm{MHPD}$

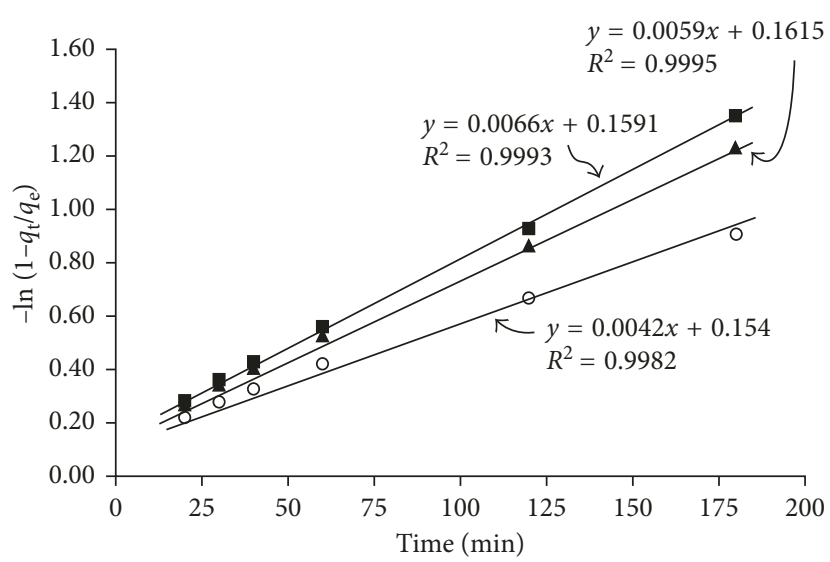

- $20 \mathrm{MHP}$

ه $35 \mathrm{MHP}$

○ $50 \mathrm{MHP}$

(b)

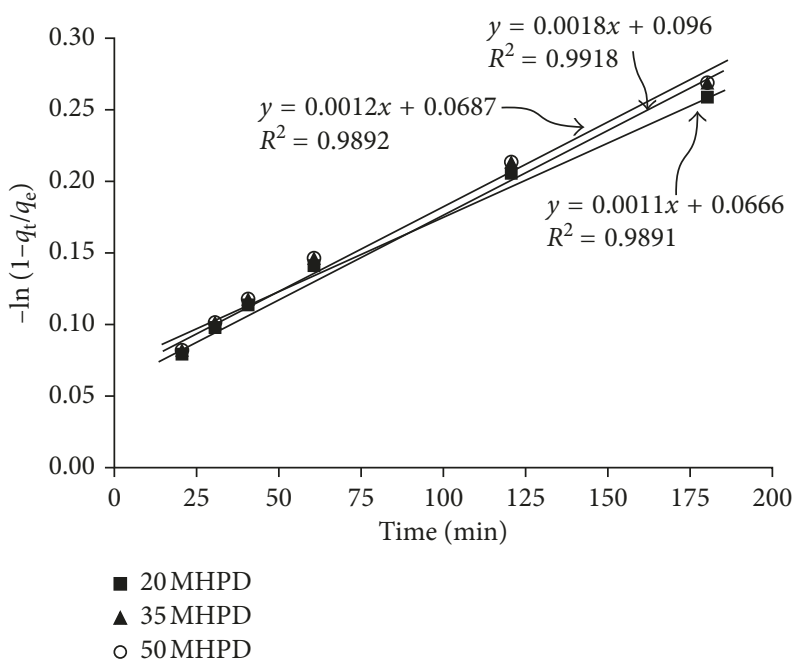

(d)

Figure 8: Intraparticle and liquid film diffusion of MHP (a, b) and MHPD (c, d) adsorbents.

$\mathrm{H}_{2} \mathrm{O}_{2}$ increased (20 MHP, 35 MHP, and $50 \mathrm{MHP}$ ) was probably due to the high density of oxygenated groups on the surface imparted by a high concentration of $\mathrm{H}_{2} \mathrm{O}_{2}$ leading to the high affinity for cations. On the other hand, the removal increased with increasing $\mathrm{H}_{2} \mathrm{O}_{2}$ concentration for MHPD because of higher concentration of DPC which favored removal of $\mathrm{Cr}(\mathrm{VI})$ at low $\mathrm{pH}$ due to protonation. The results revealed that the prepared adsorbents are suitable to be used for the remediation of water contaminated with metal ions as the $\% R$ was greater than $70 \%$ except for the 50 MHP adsorbents.

\section{Conclusion}

Three different concentrations of hydrogen peroxide $(20,35$, and $50 \%$ vol.) were utilized to pretreat the Macadamia nutshell powder. The pretreatment imparts some oxygencontaining groups $(\mathrm{C}=\mathrm{O}, \mathrm{OH}$, and $\mathrm{C}-\mathrm{O}-\mathrm{C})$ on the surface of the nutshells. It was demonstrated by FTIR that the $\mathrm{H}_{2} \mathrm{O}_{2}$ treatment resulted in shifting of $\mathrm{C}=\mathrm{O}$ peak from 1712 to $1728 \mathrm{~cm}^{-1}$ and the $\mathrm{C}-\mathrm{O}$ peak from 1031 to $1029 \mathrm{~cm}^{-1}$ in comparison to the RMN. Grafting of 1,5' -diphenylcarbazide on the RMN was confirmed with FTIR, SEM, and TGA. The FTIR showed new peaks at 3333 and $1657 \mathrm{~cm}^{-1}$ attributed to $\mathrm{NH}$ and amide $\mathrm{C}=\mathrm{O}$, respectively. Successful grafting was further corroborated by the TGA curves of MHPD showing high volatility due to the presence of DPC compared to MHP. SEM micrographs of MHPD exhibited much rougher surface than the MHP, and this was associated with grafting. The BET surface area ranged from 0.0063 to $0.5093 \mathrm{~m}^{2} / \mathrm{g}$, and these were typical of biomass materials. The adsorption efficiency of MHP treated with $50 \% \mathrm{H}_{2} \mathrm{O}_{2}$ improved from 37.74 to $72.12 \mathrm{mg} / \mathrm{g}$ for the grafted materials. The improvement in adsorption capacity validated the efficiency of grafting. The adsorption process was best described by Langmuir and PSO. In addition, it was shown that 


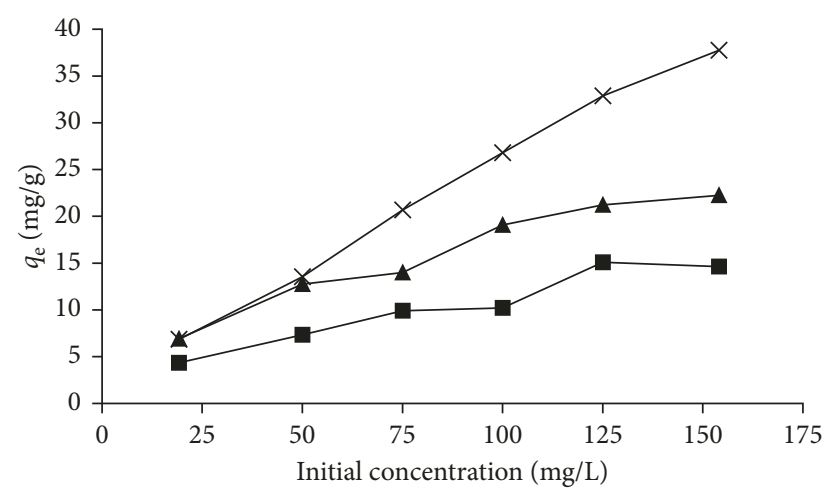

$\leftarrow 50 \mathrm{MHP}$

$\leftarrow 35 \mathrm{MHP}$

- $20 \mathrm{MHP}$

(a)

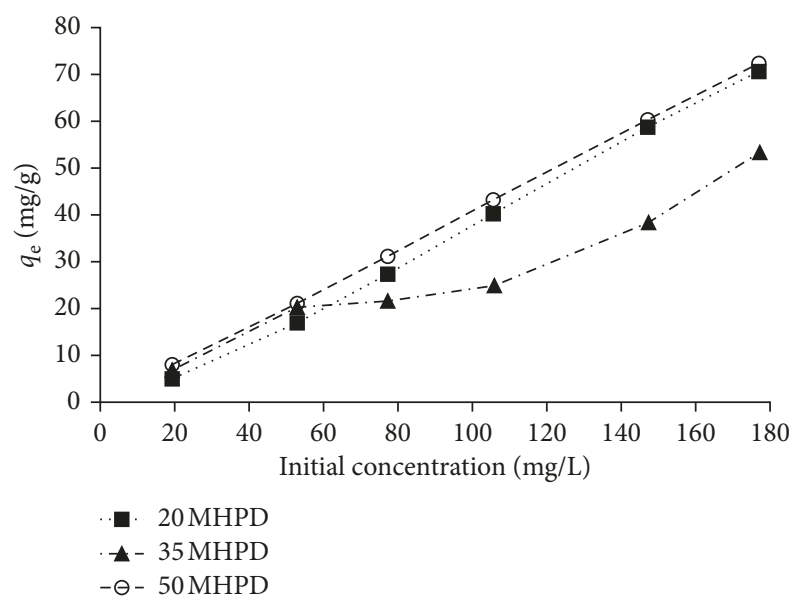

(b)

FIgURE 9: Effect of initial solution concentration for the removal of $\mathrm{Cr}(\mathrm{VI})$ by MHP and MHPD adsorbents (conditions: contact time $180 \mathrm{~min}$; dosage $2.5 \mathrm{~g} / \mathrm{L}$; and $\mathrm{pH} 2$ ).

TABle 3: Freundlich and Langmuir adsorption constants for MHP.

\begin{tabular}{|c|c|c|c|c|}
\hline Models & Parameters & 20 MHP & $35 \mathrm{MHP}$ & $50 \mathrm{MHP}$ \\
\hline \multirow{5}{*}{$\begin{array}{l}\text { Langmuir } \\
q_{\mathrm{e}}=q_{\max } \cdot b \cdot C_{\mathrm{e}} /\left(1+b C_{\mathrm{e}}\right)\end{array}$} & $q_{\mathrm{e}}(\mathrm{mg} / \mathrm{g})$ & 14.60 & 22.24 & 37.74 \\
\hline & $q_{\mathrm{m}}(\mathrm{mg} / \mathrm{g})$ & 21.77 & 27.76 & 60.59 \\
\hline & $b(\mathrm{~L} / \mathrm{mg})$ & 0.0173 & 0.0391 & 0.0189 \\
\hline & $R^{2}$ & 0.873 & 0.935 & 0.961 \\
\hline & Var* & 2.72 & 2.81 & 6.67 \\
\hline \multirow{4}{*}{$\begin{array}{l}\text { Freundlich } \\
q_{\mathrm{e}}=K_{\mathrm{F}} \cdot C_{\mathrm{e}}^{1 / \mathrm{nf}}\end{array}$} & $K_{\mathrm{F}}\left(\mathrm{mg}^{1-1 n} \mathrm{~L}^{1 / n} / \mathrm{g}\right)$ & 1.33 & 3.27 & 3.39 \\
\hline & $n_{\mathrm{F}}$ & 1.96 & 2.33 & 1.84 \\
\hline & $R^{2}$ & 0.906 & 0.947 & 0.974 \\
\hline & Var* & 2.02 & 2.29 & 4.39 \\
\hline
\end{tabular}

* Sum of square errors divided by degrees of freedom.

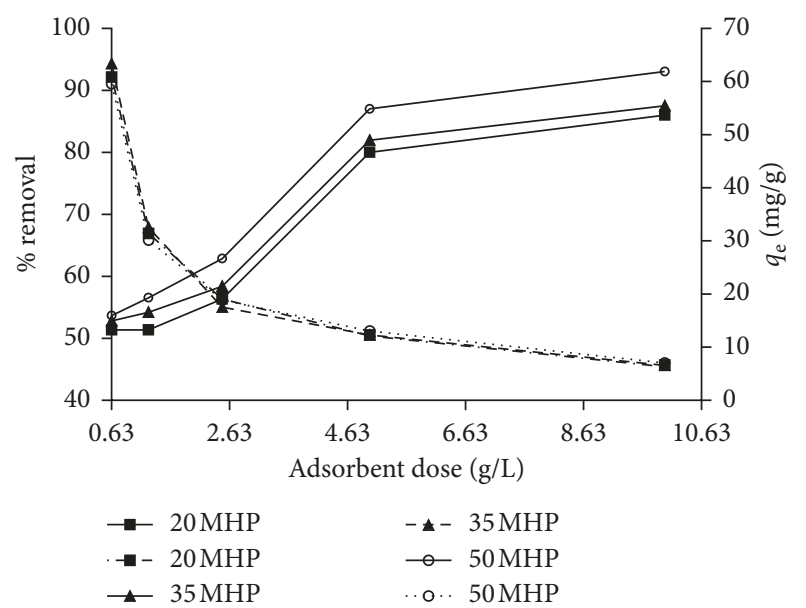

(a)

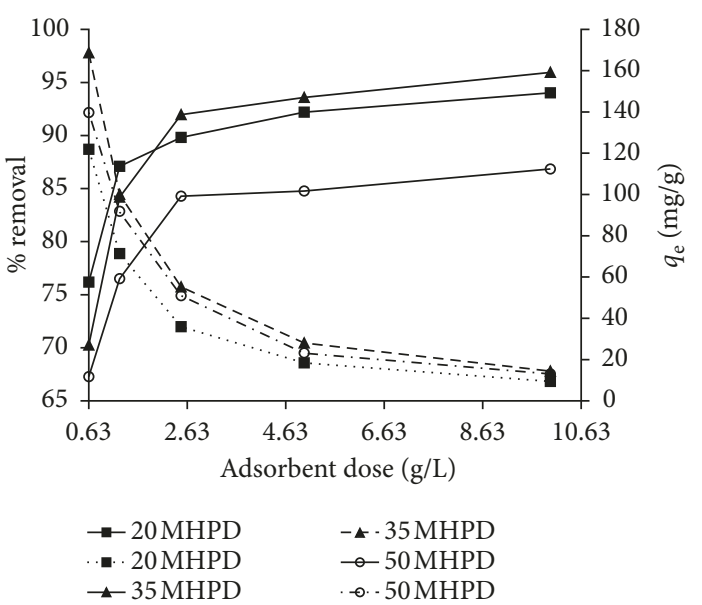

(b)

Figure 10: Effect of adsorbent dosage for the removal of Cr(VI) by MHP and MHPD adsorbents (conditions: initial Cr(VI) concentration $150 \mathrm{mg} / \mathrm{L} ; \mathrm{pH} 2$; and time $120 \mathrm{~min})$. 
TABLE 4: Comparison of adsorption capacities.

\begin{tabular}{|c|c|c|c|c|c|}
\hline Adsorbents & Pretreatment & Functionalization & $\mathrm{pH}$ & $q_{\mathrm{m}}(\mathrm{mg} / \mathrm{g})$ & References \\
\hline Potato peels & $\mathrm{HCl}$ & - & 2.5 & 3.28 & [45] \\
\hline Raw rutin & Extraction/isolation & - & 3 & 26.3 & {$[34]$} \\
\hline Rutin resin & Formaldehyde/ $\mathrm{HNO}_{3}$ & - & 3 & 41.6 & {$[34]$} \\
\hline Banana peels & $\mathrm{HCl} / \mathrm{NaOH} / \mathrm{H}_{2} \mathrm{O}_{2}$ & Acrylonitrile grafted & 3 & 6.17 & [31] \\
\hline Palm branches & $\mathrm{H}_{2} \mathrm{SO}_{4}$ & - & 2 & 25 & {$[32]$} \\
\hline Palm branches & Acetic acid & Chitosan & 6 & 55 & {$[32]$} \\
\hline Palm branches & $\mathrm{H}_{2} \mathrm{SO}_{4}$ & Cationic surfactant & 6 & 41.7 & {$[32]$} \\
\hline Grape peelings & $\mathrm{H}_{2} \mathrm{O}_{2}$ & - & 5.5 & 39.06 & {$[7]$} \\
\hline Banana peels & - & - & 5 & 3 & {$[15]$} \\
\hline Orange peels & - & - & 3 & 9 & {$[15]$} \\
\hline Coir pith & - & Acrylic acid & 2 & 165 & {$[16]$} \\
\hline Masau stones & $\mathrm{NaOH}$ & Epichlorohydrin/diethylenetriamine & 3.5 & 87.33 & [19] \\
\hline Coir pith & - & Acrylic acid & 2 & 196 & [16] \\
\hline Macadamia nutshell & $\mathrm{H}_{2} \mathrm{O}_{2}$ & - & 1 & 37.74 & This study \\
\hline Macadamia nutshell & $\mathrm{H}_{2} \mathrm{O}_{2}$ & Diphenylcarbazide & 1 & 72.12 & This study \\
\hline
\end{tabular}

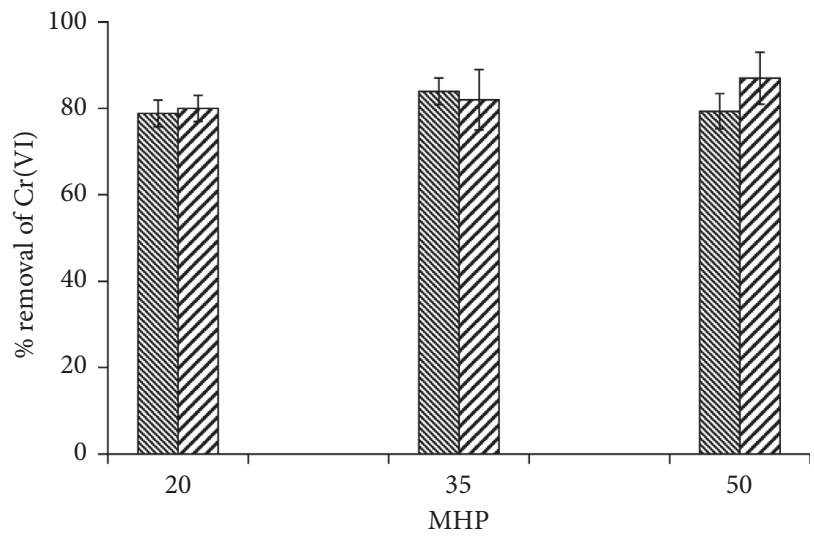

$\mathbb{\$}$ With co-ions

a No co-ions

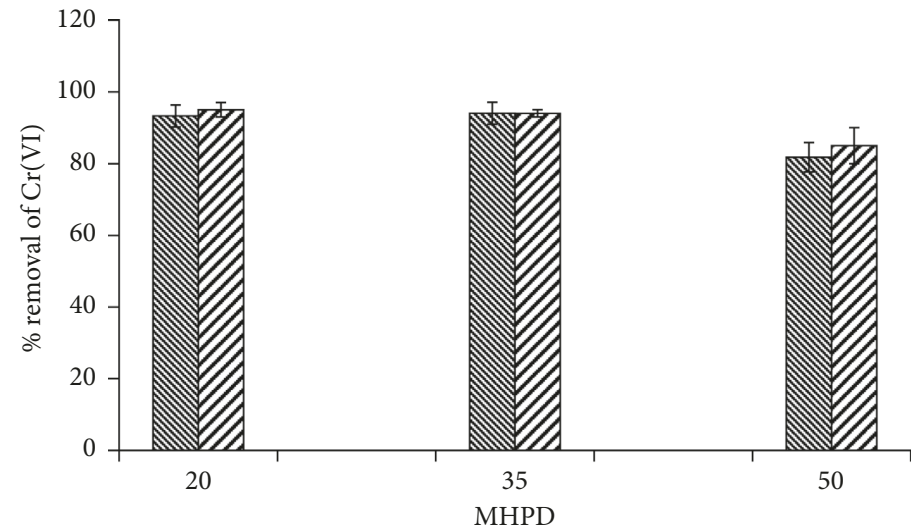

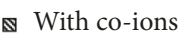

No co-ions

(a)

(b)

FIgURE 11: The effect of co-ions on the removal of $\mathrm{Cr}(\mathrm{VI})$ by MHP (a) and MHPD (b) adsorbents.

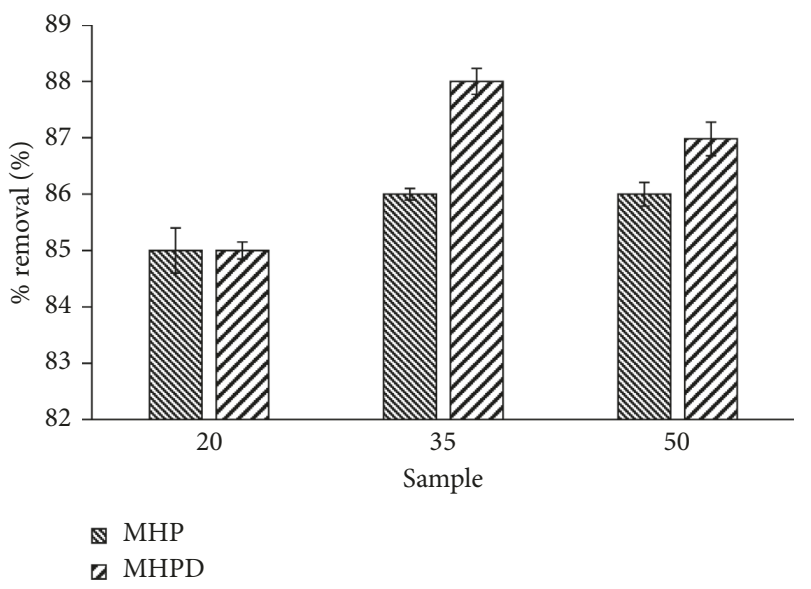

Figure 12: Real sample characteristics and removal of $\mathrm{Cr}(\mathrm{VI})$ from the real sample by MHP and MHPD adsorbents. 
intraparticle diffusion was not the only rate-controlling step. The adsorption of $\mathrm{Cr}(\mathrm{VI})$ by MHPD was less affected by the presence of competing ions as it was shown in selectivity studies and application to real-world sample.

\section{Abbreviations}

\section{DPC: $\quad 1,5^{\prime}$-diphenylcarbazide}

MHP: $\quad$ Macadamia nutshell powder oxidized by hydrogen peroxide solutions

20 MHP: Macadamia nutshell powder oxidized by $20 \%$ (v/v) hydrogen peroxide solutions

35 MHP: Macadamia nutshell powder oxidized by $35 \%$ (v/v) hydrogen peroxide solutions

50 MHP: Macadamia nutshell powder oxidized by $50 \%$ $(\mathrm{v} / \mathrm{v})$ hydrogen peroxide solutions

20 MHPD: 20 MHP adsorbent grafted with DPC

35 MHPD: 35 MHP adsorbent grafted with DPC

50 MHPD: 50 MHP adsorbent grafted with DPC

BET: $\quad$ Brunauer-Emmett-Teller

DTA: Differential thermal analysis

EDX: $\quad$ Energy dispersive X-ray

FTIR: $\quad$ Fourier transform infrared spectroscopy

LOD: Limit of detection

PFO: $\quad$ Pseudo-first order

PSO: $\quad$ Pseudo-second order

RMN: $\quad$ Raw Macadamia nutshell

SEM: $\quad$ Scanning electron microscopy

TGA: Thermogravimetric analysis.

\section{Additional Points}

Highlights. Macadamia nutshell powder was oxidized with hydrogen peroxide. The peroxide-modified materials were grafted with diphenylcarbazide. Grafting with diphenylcarbazide improved the adsorption capacity. Presence of co-ions did not influence the removal efficiency. Adsorbents demonstrated good recoveries when subjected to real-world sample.

\section{Conflicts of Interest}

The authors declare that they have no conflicts of interest.

\section{Acknowledgments}

The National Research Foundation (TTK13061018779 and TTK160510164648) and the Vaal University of Technology financial support are gratefully appreciated.

\section{References}

[1] W. S. W. Ngah and M. A. K. M. Hanafiah, "Removal of heavy metal ions from wastewater by chemically modified plant wastes as adsorbents: a review," Bioresource Technology, vol. 99, no. 10, pp. 3935-3948, 2008.

[2] J. L. Gardea-Torresdey, M. K. Becker-Hapak, J. M. Hosea, and D. W. Darnall, "Effect of chemical modification of algal carboxyl groups on metal ion binding," Environmental Science \& Technology, vol. 24, no. 9, pp. 1372-1378, 1990.
[3] H. Kołoczek, J. Chwastowski, and W. Żukowski, "Peat and coconut fiber as biofilters for chromium adsorption from contaminated wastewaters," Environmental Science and Pollution Research, vol. 23, no. 1, pp. 527-534, 2016.

[4] V. E. Pakade, T. D. Ntuli, and A. E. Ofomaja, "Biosorption of hexavalent chromium from aqueous solutions by Macadamia nutshell powder," Applied Water Science, vol. 7, no. 6, pp. 3015-3030, 2017.

[5] R. Kumar, R. K. Sharma, and A. P. Singh, "Cellulose-based grafted biosorbents-journey from lignocellulose biomass to toxic metal ions sorption applications-a review," Journal of Molecular Liquids, vol. 232, pp. 62-93, 2017.

[6] S. J. Köhler, P. Cubillas, J. D. Rodriguez-Blanco, C. Bauer, and M. Prieto, "Removal of cadmium from wastewaters by aragonite shells and the influence of other divalent cations," Environmental Science \& Technology, vol. 41, no. 1, pp. 112118, 2007.

[7] E. Rosales, J. Meijide, T. Tavares, M. Pazos, and M. A. Sanromán, "Grapefruit peelings as a promising biosorbent for the removal of leather dyes and hexavalent chromium," Process Safety and Environmental Protection, vol. 101, pp. 61-71, 2016.

[8] X. Liu, Z. Q. Chen, B. Han, C. L. Su, Q. Han, and W. Z. Chen, "Biosorption of copper ions from aqueous solution using rape straw powders: optimization, equilibrium and kinetic studies," Ecotoxicology and Environmental Safety, vol. 150, pp. 251-259, 2018.

[9] A. Abdolali, W. S. Guo, H. H. Ngo, S. S. Chen, N. C. Nguyen, and K. L. Tung, "Typical lignocellulosic wastes and byproducts for biosorption process in water and wastewater treatment: a critical review," Bioresource Technology, vol. 160, pp. 57-66, 2014.

[10] J. Putro, F. Soetaredjo, S. Lin, Y. Ju, and S. Ismadji, "Pretreatment and conversion of lignocellulose biomass into valuable chemicals," RSC Advances, vol. 6, no. 52, pp. 46834-46852, 2016.

[11] R. H. Vieira and B. Volesky, "Biosorption: a solution to pollution?," International Microbiology, vol. 3, no. 1, pp. 17-24, 2000.

[12] Z. Kádár, N. Schultz-Jensen, J. S. Jensen, M. A. T. Hansen, F. Leipold, and A.-B. Bjerre, "Enhanced ethanol production by removal of cutin and epicuticular waxes of wheat straw by plasma assisted pretreatment," Biomass and Bioenergy, vol. 81, pp. 26-30, 2015.

[13] Y. H. P. Zhang, S. Y. Ding, J. R. Mielenz et al., "Fractionating recalcitrant lignocellulose at modest reaction conditions," Biotechnology and Bioengineering, vol. 97, no. 2, pp. 214-223, 2007.

[14] M. E. Himmel, W. S. Adney, J. O. Baker et al., "Advanced bioethanol production technologies: a perspective," ACS Symposium Series, vol. 666, pp. 2-45, 1997.

[15] K. Pakshirajan, A. N. Worku, M. A. Acheampong, H. J. Lubberding, and P. N. L. Lens, "Cr(III) and $\mathrm{Cr}(\mathrm{VI})$ removal from aqueous solutions by cheaply available fruit waste and algal biomass," Applied Biochemistry and Biotechnology, vol. 170, no. 3, pp. 498-513, 2013.

[16] P. Suksabye and P. Thiravetyan, "Cr(VI) adsorption from electroplating plating wastewater by chemically modified coir pith," Journal of Environmental Management, vol. 102, pp. 1-8, 2012.

[17] M. Behbahani, A. Bagheri, M. M. Amini et al., "Application of multiwalled carbon nanotubes modified by diphenylcarbazide for selective solid phase extraction of ultra-traces Cd(II) in water samples and food products," Food Chemistry, vol. 141, no. 1, pp. 48-53, 2013.

[18] N. Tka, M. Jabli, T. A. Saleh, and G. A. Salman, "Amines modified fibers obtained from natural Populus tremula and 
their rapid biosorption of Acid Blue 25," Journal of Molecular Liquids, vol. 250, pp. 423-432, 2018.

[19] A. B. Albadarin, S. Solomon, T. A. Kurniawan, C. Mangwandi, and G. Walker, "Single, simultaneous and consecutive biosorption of $\mathrm{Cr}(\mathrm{VI})$ and Orange II onto chemically modified masau stones," Journal of Environmental Management, vol. 204, pp. 365-374, 2017.

[20] V. E. Pakade, L. C. Maremeni, T. D. Ntuli, and N. T. Tavengwa, "Application of quaternized activated carbon derived from Macadamia nutshells for the removal of hexavalent chromium from aqueous solutions," South African Journal of Chemistry, vol. 69, pp. 180-188, 2016.

[21] I. Polowczyk, B. F. Urbano, B. L. Rivas, M. Bryjak, and N. Kabay, "Equilibrium and kinetic study of chromium sorption on resins with quaternary ammonium and N-methyl-D-glucamine groups," Chemical Engineering Journal, vol. 284, pp. 395-404, 2016.

[22] K. Selvarag, S. Manonmani, and S. Pattabhi, "Removal of hexavalent chromium using distillery sludge," Bioresource Technology, vol. 89, no. 2, pp. 207-211, 2003.

[23] E. Browning, Chromium in Toxicity of Industrial Metals, Butterworths and Co., London, UK, 2nd edition, 1969.

[24] M. Cieslak-Golonka, "Toxic and mutagenic effects of chromium(VI)," Polyhedron, vol. 15, no. 21, pp. 3667-3689, 1995.

[25] V. E. Pakade, O. B. Nchoe, L. Hlungwane, and N. T. Tavengwa, "Sequestration of hexavalent chromium from aqueous solutions by activated carbon derived from Macadamia nutshells," Water Science and Technology, vol. 75, no. 1, pp. 196-206, 2017.

[26] E. M. Kalhori, K. Yetilmezsoy, N. Uygur, M. Zarrabi, and R. M. A. Shmeis, "Modeling of adsorption of toxic chromium on natural and surface modified lightweight expanded clay aggregate (LECA)," Applied Surface Science, vol. 287, pp. $428-442,2013$.

[27] A. Demirbas, "Mechanisms of liquefaction and pyrolysis reactions of biomass," Energy Conversion and Management, vol. 41, no. 6, pp. 633-646, 2000.

[28] C. Paduraru, L. Tofan, C. Teodosiu, I. Bunia, N. Tudorachi, and O. Toma, "Biosorption of zinc(II) on rapeseed waste: equilibrium studies and thermogravimetric investigations," Process Safety and Environmental Protection, vol. 94, pp. 1828, 2015.

[29] H. Yang, R. Yan, H. Chen, D. H. Lee, and C. Zheng, "Characteristics of hemicellulose, cellulose and lignin pyrolysis," Fuel, vol. 86, no. 12-13, pp. 1781-1788, 2007.

[30] R. P. Dhakal, K. N. Ghimire, and K. Inoue, "Adsorptive separation of heavy metals from an aquatic environment using orange waste," Hydrometallurgy, vol. 79, no. 3-4, pp. 182-190, 2005.

[31] A. Ali, K. Saeed, and F. Mabood, "Removal of chromium (VI) from aqueous medium using chemically modified banana peels as efficient low-cost adsorbent," Alexandria Engineering Journal, vol. 55, no. 3, pp. 2933-2942, 2016.

[32] M. M. Shouman, N. A. Fathy, S. A. Khedr, and A. A. Attia, "Comparative biosorption studies of hexavalent chromium ion onto raw and modified branches," Advances in Physical Chemistry, vol. 2013, Article ID 159712, 9 pages, 2013.

[33] J. Chwastowski, P. Staroń, H. Kołoczek, and M. Banach, "Adsorption of hexavalent chromium from aqueous solutions using Canadian peat and coconut fiber," Journal of Molecular Liquids, vol. 248, pp. 981-989, 2017.

[34] N. A. Fathy, S. T. El-Wakeel, and R. R. Abd El-Latif, "Biosorption and desorption studies on chromium(VI) by novel biosorbents of raw rutin and rutin resin," Journal of
Environmental Chemical Engineering, vol. 3, no. 2, pp. 1137-1145, 2015.

[35] S. O. Owalude and A. C. Tella, "Removal of hexavalent chromium from aqueous solutions by adsorption on modified groundnut hull," Beni-Suef University Journal of Basic and Applied Sciences, vol. 5, no. 4, pp. 377-388, 2017.

[36] M. Jain, V. K. Garg, and K. Kadirvelu, "Adsorption of hexavalent chromium from aqueous medium onto carbonaceous adsorbents prepared from waste biomass," Journal of Environmental Management, vol. 91, no. 4, pp. 949-957, 2010.

[37] Y. Sun, Q. Yue, B. Gao, Y. Gao, Q. Li, and Y. Wang, “Adsorption of hexavalent chromium on Arundo donax Linn activated carbon amine-crosslinked copolymer," Chemical Engineering Journal, vol. 217, pp. 240-247, 2013.

[38] L. Hlungwane, E. L. Viljoen, and V. E. Pakade, "Macadamia nutshells derived activated carbon and attapulgite clay combination for synergistic removal of $\mathrm{Cr}(\mathrm{VI})$ and $\mathrm{Cr}(\mathrm{III})$," Adsorption Science \& Technology, vol. 36, no. 1-2, pp. 713-731, 2017.

[39] S. Lagergren, "Zur theorie der sogenannten adsorption geloster stoffe," Kungliga Sevenska Vetenskapas Akademiens, vol. 24, pp. 1-39, 1898.

[40] Y. S. Ho and G. McKay, "Pseudo-second order model for sorption processes," Process Biochemistry, vol. 34, no. 5, pp. 451-465, 1999.

[41] R. L. Tseng and S. K. Tseng, "Pore structure and adsorption performance of the $\mathrm{KOH}$ activated carbons prepared from corncob," Journal of Colloid and Interface Science, vol. 87, no. 2, pp. 428-437, 2005.

[42] W. J. Weber, J. C. Morris, and J. Sanit, "Kinetics of adsorption on carbon from solution," Journal of the Sanitary Engineering Division-Civil Engineering, vol. 89, no. 2, pp. 31-60, 1963.

[43] V. J. P. Poots, G. McKay, and J. J. Healy, "The removal of acid dye from effluent, using natural adsorbents: I peat," Water Research, vol. 10, no. 12, pp. 1061-1066, 1976.

[44] P. Saha, "Assessment of the removal of methylene blue dye using tamarind fruit shell as biosorbent," Water, Air, \& Soil Pollution, vol. 213, no. 1-4, pp. 287-299, 2010.

[45] K. M. Doke and E. M. Khan, "Equilibrium, kinetic and diffusion mechanism of $\mathrm{Cr}(\mathrm{VI})$ adsorption onto activated carbon derived from wood apple shell," Arabian Journal of Chemistry, vol. 10, pp. S252-S260, 2017.

[46] F. Mutongo, O. Kuipa, and P. K. Kuipa, "Removal of Cr(VI) from aqueous solutions using powder of potato peelings as a low cost sorbent," Bioinorganic Chemistry and Applications, vol. 2014, Article ID 973153, 7 pages, 2014.

[47] C. Namasivayam, K. Kadirvelu, and M. Kumuthu, "Removal of direct red and acid brilliant blue by adsorption on to banana pith," Bioresource Technology, vol. 64, no. 1, pp. 77-79, 1998.

[48] V. Neagu and S. Mikhalovsky, "Removal of hexavalent chromium by new quaternized crosslinked poly(4-vinylpyridines)," Journal of Hazardous Materials, vol. 183, no. 1-3, pp. 533-540, 2010.

[49] V. Pakade, E. Cukrowska, J. Darkwa, N. Torto, and L. Chimuka, "Selective removal of chromium (VI) from sulphates and other metal anions using an ion-imprinted polymer," Water SA, vol. 37, no. 4, pp. 529-537, 2011. 

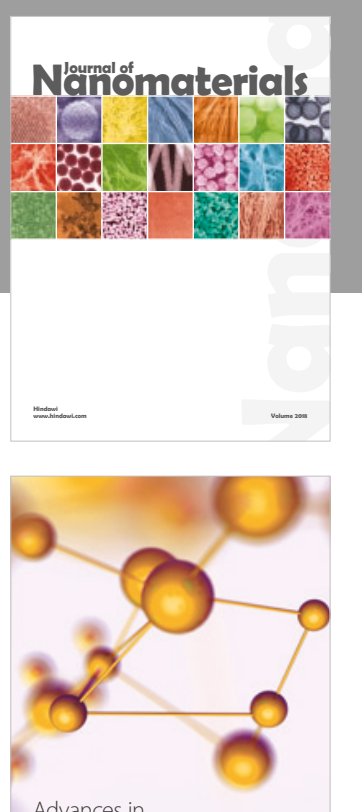

Physical Chemistry
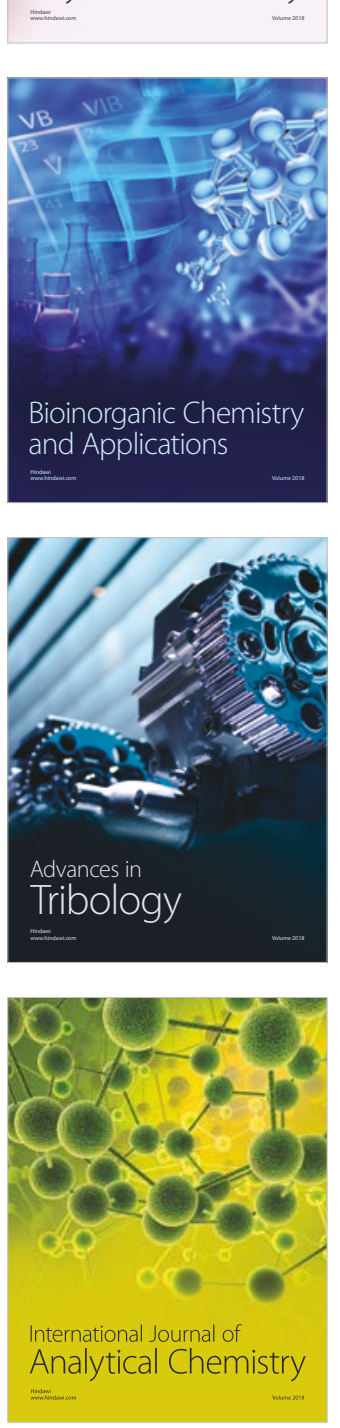

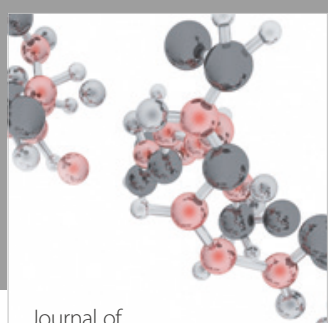

Analytical Methods

in Chemistry

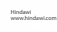

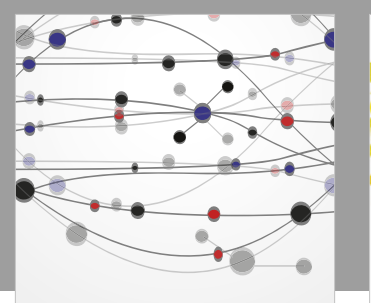

The Scientific World Journal

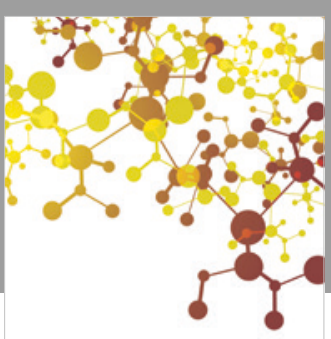

Journal of

Applied Chemistry
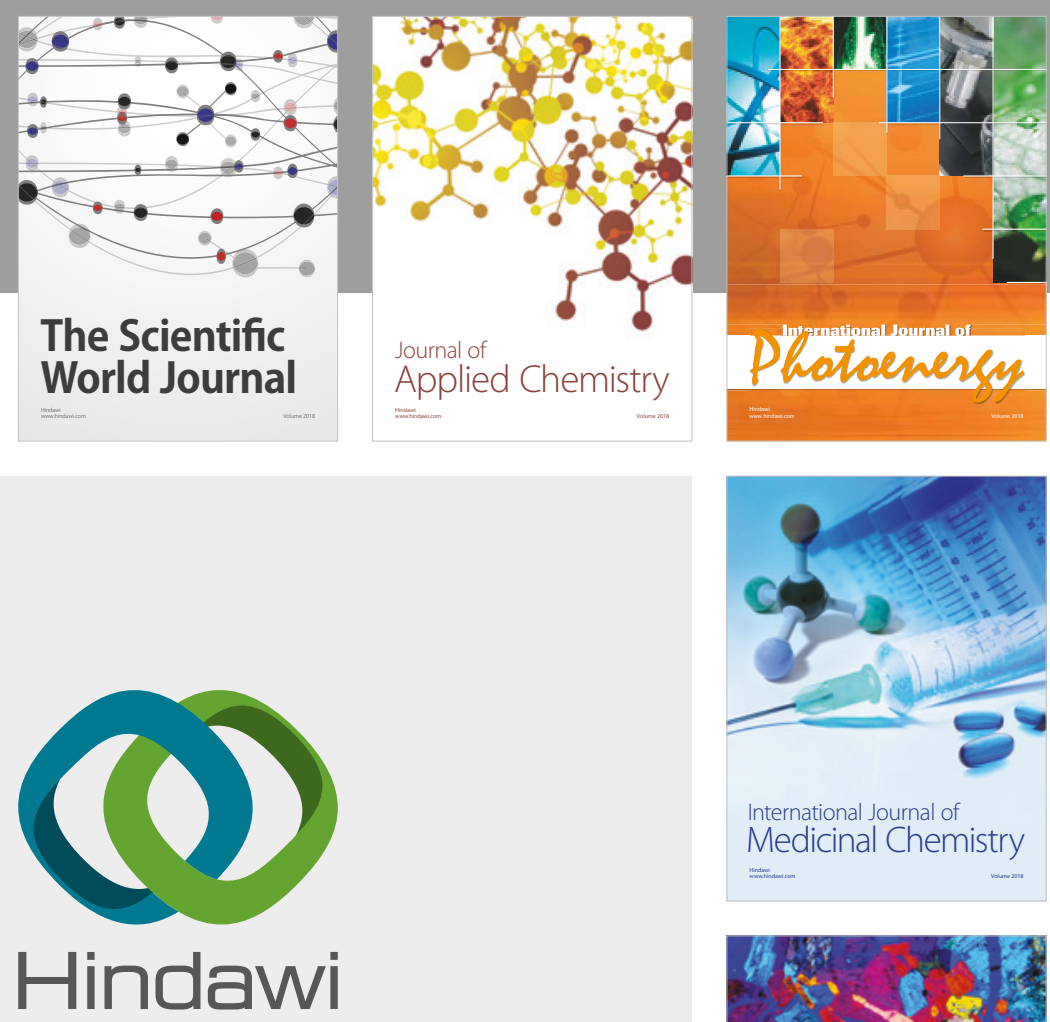

Submit your manuscripts at

www.hindawi.com
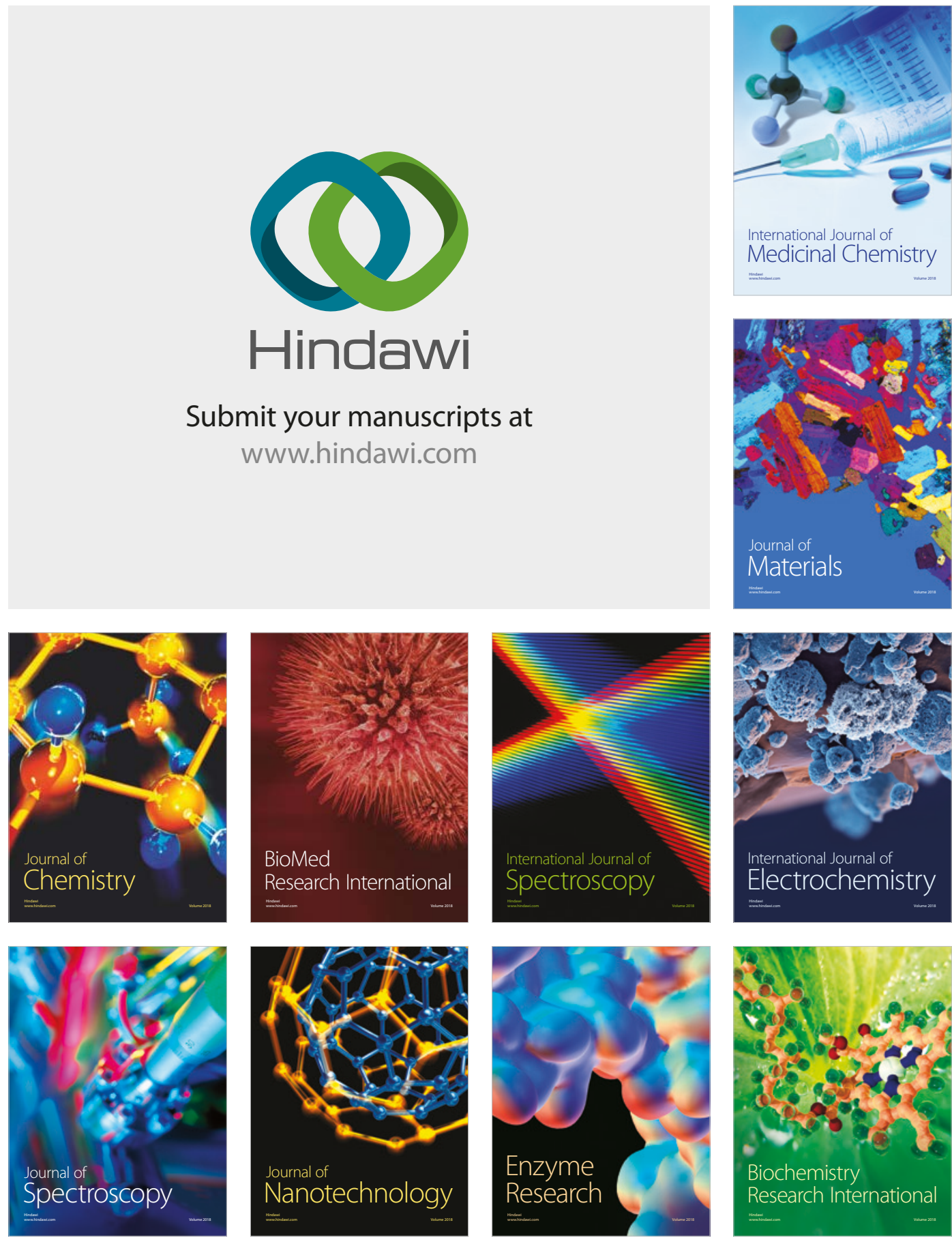
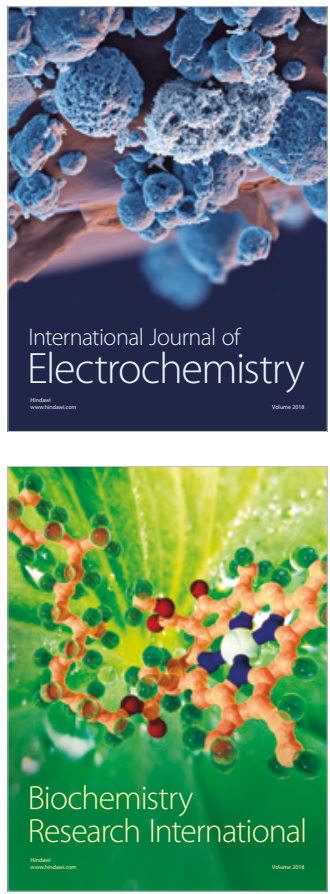